\title{
THE STRATEGIC IMPACT OF AIRLINE GROUP DIVERSIFICATION: THE CASES OF EMIRATES AND LUFTHANSA
}

\author{
Redpath, $\mathrm{N}^{\mathrm{a}}$., O’Connell. J.F ${ }^{\mathrm{a}^{*}}$, and Warnock-Smith, $\mathrm{D}^{\mathrm{b}}$.
}

${ }^{\mathrm{a}}$ Centre for Air Transport Management, Cranfield, University, Cranfield, Bedfordshire, England, UK, MK43 OAG

${ }^{\mathrm{b}}$ Division of Logistics, Transport and Tourism, University of Huddersfield, Queensgate, Huddersfield, England, UK, HD1 3DH

*Corresponding author 


\title{
THE STRATEGIC IMPACT OF AIRLINE GROUP DIVERSIFICATION: THE CASES OF EMIRATES AND LUFTHANSA
}

\begin{abstract}
The airline industry is a diverse sector, requiring the support of a varied range of ancillary businesses such as maintenance, catering and travel agencies to carry out its activities. Many of these supporting businesses demonstrate the potential to drive wider profit margins despite generating lower revenues than the airlines themselves, making them attractive investment opportunities in a sector prone to volatile and often lacklustre trading. This study investigates two of the largest diversified airline groups, Germany's Lufthansa Group and Dubai's Emirates Group, each adopting a distinct approach towards diversification that may serve as a model for airline groups worldwide. The areas investigated were Cargo, Maintenance, Catering and Travel Services. The research found that whilst diversification may not always present the most attractive option financially, strategic factors can often outweigh such concerns. Business units studied were found to have variable prospects; particularly in the case of Catering, a sector on the rise - versus in-house Maintenance, which for airlines, is likely to see decline. The pursuit of third party revenue streams to offset weak internal trading and growth of competencies were found to be the key drivers of success. Interplay between segments was also apparent, showing that a well-organised diversification strategy can achieve robust cross-functional benefits and deliver significant value to the parent organisation.
\end{abstract}

Key words: Airline diversification, Airline Groups, Strategic direction 


\section{Introduction}

Corporate diversification within the airline business has a long history. Many of the first airlines were initiated as related sub-ventures by existing transport-focused organisations; such as United Airlines, which can trace its lineage to Boeing Air Transport in 1927 (Rodgers, 1996). As the industry grew and matured, Pan American World Airways came to epitomise the concept of a global aviation services empire, with subsidiaries such as Pan Am World Services and the still active Intercontinental Hotels brand, allowing it to strategically extend its reach into higher margin sectors, whilst supporting the objectives and needs of its core business.

In a highly-cyclical business such as air transport, it is arguably difficult to maintain a longterm strategic scope whilst managing non-core assets effectively. The Emirates and the Lufthansa Groups are both highly successful airline conglomerates but given the propensity for diversified business units to often outperform the core passenger business of an airline, the question arises as to what their overall contribution to core results are.

This will be investigated through a specific analysis of the Lufthansa and Emirates Groups, both individually and comparatively. Each has been chosen due to their industry prevalence and ability to serve as emblematic representations of legacy carriers, acting as bellwethers for broader industry trends. The business units focussed upon have been chosen on the basis of the size of their revenue contributions to each group. These units are shown in Table 1.

Table 1 Business Units Investigated

\begin{tabular}{|l|l|l|}
\hline Company & Business Unit & Market Sector \\
\hline \multirow{4}{*}{ Emirates } & SkyCargo & Cargo/air freight \\
\cline { 2 - 3 } & DLM and Travel Services & Travel \\
\cline { 2 - 3 } & Catering & Flight Catering \\
\hline \multirow{3}{*}{ Lufthansa } & Logistics & Cargo/air freight \\
\cline { 2 - 3 } & Technik & $\begin{array}{l}\text { Maintenance Repair and } \\
\text { Overhaul }\end{array}$ \\
\cline { 2 - 3 } & LSG SkyChefs & Flight Catering \\
\hline
\end{tabular}

The study's specific research questions are to discover how diversified business units drive airline parent company strategy and vice versa, how the strategic value of an airline business unit is measured and how individual business units belonging to larger airline Groups succeed or fail. The overriding aim of the study is to investigate how the present state of airline business diversification has been achieved at both Lufthansa and Emirates.

This study is not intended to determine if there is any particular 'right or wrong' way to pursue diversification, but instead to analyse how diversified business units might assist parent airline groups in achieving their corporate objectives, using a mix of qualitative and quantitative methodologies as described in Figure 1. 
Figure 1 Methodology Outline

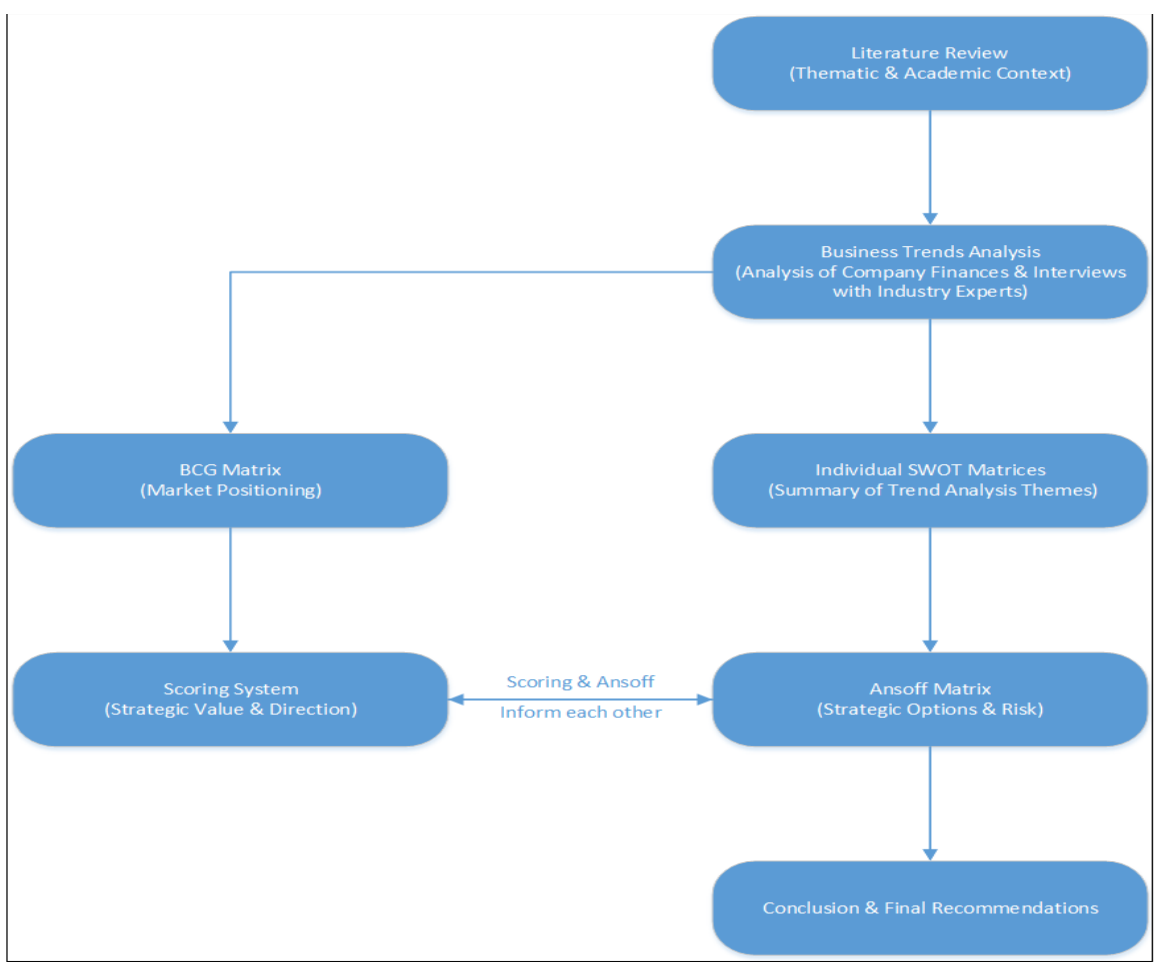

Initial context will be provided by a review of relevant company and airline diversification literature (Section 2). The data and methods strategy is then summarised in Section 3.

Thematic areas for further analysis stemming from the literature review process were merged together with a quantitative assessment of Group financial records and trends for the period 2009-2014 along with a unique Strategic Scoring Method especially adapted for this study (Section 4). Commonly applied BCG and ANSOFF frameworks (Section 5) are finally devised for the two airline Groups to arrive at a set of reliable conclusions and recommendations (Section 6). Excerpts from industry experts interviewed for this study are reported across sections 2 to 6 in support of the quantitative data on the two airline groups.

\section{Diversification as a strategy}

Although diversification is a well-researched phenomenon in academic literature, having been explored by noted economists (Schumpeter, 1942 in Dinapoulis, 1994. Ansoff, 1957. Porter, 1980. Teece, 1986), there is a relative dearth of material relating directly to the topic of airline diversification strategy from a group, or umbrella-company viewpoint. Case-bycase analysis has been carried out in recent years (Heracleous, 2004, Lindstädt and Fauser, 2004, Jones, 2007), with attention paid to their individual contributions.

Aside from the core competency of flying passengers, airlines have sought to diversify and extend the reach of their capabilities and revenue streams. It has been shown to have a significant impact on company fortunes (Hitt et al, 1997), provided the nature of the firm's strategy is 'related' (Geringer et al, 2000) in some way to its core competency. Where firms engage in 'unrelated' diversification - whereby Business Units (BU's) lack commonality and 
fail to support the core competency - potential for sharing of benefits is reduced, resulting in an inflation of cost and dilution of management expertise and organisational resources (Campbell, 1992).

Common airline diversification strategies have encompassed Cargo, Maintenance Repair and Overhaul (MRO), Catering, Information Technology (IT) and Leisure Management / Travel Agencies (Jenkins et al, 2012, O’Connell, 2007, Suen, 2002). As such, related diversification within the air transport industry seeks to support passenger operations with business units providing relevant or aligned services. For example, cargo may be seen as a direct by-product of airlines' seeking to leverage otherwise unused bellyhold capacity - with some then diversifying further into pure-freighter operations. Additionally, an integrated IT business unit may serve to support an airline's booking system, upon which it is heavily dependent.

The motives behind airline group diversification are closely linked to strategic market positioning (Porter, 1980) and growth (Ansoff, 1957). Ansoff notes that a company's avenues to growth are fourfold: enhanced market penetration, market stimulation, product development or diversification - the latter carrying the most risk if mishandled, but the least if executed competently. However, Ansoff's growth solution does not account for the need to negate strategic threats. As a standalone business, a company may not be able to respond to competitors through core activities alone. Here diversification may aid in fulfilling Porter's need for a company to 'relate to its environment' to achieve strategic success. A group's ability to exhibit strength in all aspects of Porter's 'five forces' model will inform and validate its underlying ability to deliver profits (O'Connell, 2007). An example of an airline group successfully engaging with the five forces through leveraging non-core business units can be seen in the Emirates Group's diversification strategy, as illustrated in Table 2. 
Table 2 Emirates' Response to Porters 5 Forces

\begin{tabular}{|c|c|c|c|}
\hline Force & Threat & Reason(s) & Response(s) \\
\hline \multirow[t]{2}{*}{ Competitive Rivalry } & \multirow[t]{2}{*}{ Very High } & $\begin{array}{l}\text { Fast growing local } \\
\text { competition }\end{array}$ & \multirow[t]{2}{*}{$\begin{array}{l}\text { Joint-venture with } \\
\text { Qantas }\end{array}$} \\
\hline & & $\begin{array}{l}\text { Legacy carriers } \\
\text { successfully reducing } \\
\text { costs }\end{array}$ & \\
\hline \multirow[t]{2}{*}{$\begin{array}{l}\text { Supplier Bargaining } \\
\text { Power }\end{array}$} & \multirow[t]{2}{*}{ Moderate } & $\begin{array}{l}\text { Strong global MRO } \\
\text { sector controlled by } \\
\text { competitors }\end{array}$ & $\begin{array}{l}\text { Establishement of } \\
\text { EK Engineering as a } \\
\text { regional leader }\end{array}$ \\
\hline & & $\begin{array}{l}\text { Need for flight } \\
\text { caterting at all points } \\
\text { of call }\end{array}$ & $\begin{array}{l}\text { Global covergage of } \\
\text { Dnata catering } \\
\text { operations }\end{array}$ \\
\hline $\begin{array}{l}\text { Buyer Bargaining } \\
\text { Power }\end{array}$ & High & $\begin{array}{l}\text { Increasing } \\
\text { dominance of online } \\
\text { price-comparison }\end{array}$ & $\begin{array}{l}\text { Growth of Emirates- } \\
\text { owned direct sales } \\
\text { channels }\end{array}$ \\
\hline $\begin{array}{l}\text { Threat of Potential } \\
\text { Entrants }\end{array}$ & High & $\begin{array}{l}\text { Rise of well-financed } \\
\text { rivals: Etihad, Qatar, } \\
\text { Turkish and Air } \\
\text { Arabia }\end{array}$ & $\begin{array}{l}\text { Launch of flydubai to } \\
\text { tackle Air Arabia and } \\
\text { reduce threat from } \\
\text { other current and } \\
\text { would-be LCCs }\end{array}$ \\
\hline & & & $\begin{array}{l}\text { Launch of Emirates } \\
\text { Executive* }\end{array}$ \\
\hline Threat of Substitutes & Low & $\begin{array}{l}\text { Teleconferencing } \\
\text { growth prompted by } \\
\text { financial crisis }\end{array}$ & $\begin{array}{l}\text { Focus on Business } \\
\text { Rewards Programme } \\
\text { (with growing } \\
\text { number of } \\
\text { participating } \\
\text { partners) }\end{array}$ \\
\hline
\end{tabular}

*Emirates Executive is a response in part to Qatar Executive and Etihad 'The Residence' product Source Author research/interviews

Here it is observable that in addition to responding to the threats of 'Competitive Rivalry' and 'Potential Entrants' with core-competencies, the remainder of Emirates' diversified structure aids in creating a stronger platform to bolster its strategic position within Porter's forces framework. In each instance, Emirates is able to deliver an in-house solution from its diversified portfolio to meet strategic issues relevant to its passenger transport business, despite said solutions not directly involving the transport of passengers. For example, services arm Dnata is able to cover much of Emirates' global catering needs whilst also generating incremental revenue by supplying the needs of competitors. This is known as 'Economies of Diversification' (Berger and Humphrey, 1991. Grosskopf et al, 1992, Chavas and Kim, 2010), whereby the economies of scale and scope provided by growing the business to supply the market at large ultimately serve to make Emirates' own catering more costeffective, strengthen its strategic standing and delivering tangible returns to the core-business. Beyond strategic positioning, it is important to note the desire of airlines to avoid overspecialisation in a high-risk, low-margin industry. Diversification empowers airlines to avoid 
dependence on one product line, to achieve greater stability of profits, to make greater use of an existing distribution system and to acquire value chain know-how.

Kock and Guillen (2001) assert that the diversification strategy pursued by a firm is inherently informed by its competencies by default. This may be seen in the air transport industry through the proliferation of related ventures helping to drive the core strategy of an airline group. For example, Lufthansa Group has grown its expertise derived from the need to deliver internal Information Technology solutions through establishing and growing its IT division. This supports the airline's need for cost-effective IT projects, but is controlled by the corporate principals of the Lufthansa Group ${ }^{1}$. Associated benefits include the elimination of the need to constantly reinforce service level agreements with third party suppliers, as well as a corresponding reduction in the number of potentially difficult to control variables in its IT supply chain (Jones, 2007), such as software development and systems maintenance.

Ketler and Walstrom (1993) note that outsourcing is impacted heavily by organisational characteristics, as well as vendor and contract issues. Within the airline industry, evidence exists to illustrate that diversification represents a more controllable (Pakneiat et al, 2010) and more administrable (Heracleous et al, 2004) alternative for carriers which possess the scale to fully realise the benefits of its adoption.

MRO serves as a useful example of a revenue stream that can provide significant tangible benefits, but also incur large costs. With the potential to represent 10-15\% of an airline's operational overheads (Al-Kaabi, Potter and Naim, 2007, Kilpi and Ari, 2004, CAPA, 2014), MRO presents a compelling case for pursuing an outsourcing strategy when viewed at face value. However, where in-demand technical competency can be married to the prospect of generating incremental revenue, in-sourcing functions such as MRO can pay notable dividends - provided the business unit is capable of supplying third parties to a meaningful degree of revenue generation. An example of this may be seen in Delta Airlines' investing in AeroMexico for the primary purpose of building its MRO portfolio (CAPA, 2011). Heracleous et al. $(2004,2009)$ highlight the notion that related diversification into higher margin sectors not only provides healthy alternative revenue streams, but also in their analysis of Singapore Airlines Engineering provide practical evidence of a business unit simultaneously servicing the core business (Singapore Airlines), as well as improving grouplevel costs and reinforcing group service standards.

Where a carrier lacks the scale to profitably support its own needs and sell to third parties, the prospect of diversification may seem less attractive (Heikkila and Cordon, 2002); conversely a carrier of Lufthansa's scale arguably allows it to overcome high competitive density, with seven out of ten of its major competitors operating major MRO businesses in close regional proximity (Tegtmeier, 2005 in Aviation Week, 2011). As such, when applied in scale, diversification presents a sensible strategic option, especially if viewed from the perspective

\footnotetext{
${ }^{1}$ Personal interview with Harald Heppner, Manager Corporate Strategy, Lufthansa Group.
} 
that MRO in particular is a more stable business than passenger transport - positioning it as an offset against the cyclicality of the airline business (Kilpi and Vepsalainen, 2004).

Ansoff supports this notion, noting, "if (a firm's) diversification objective is to correct cyclic variations in demand that are characteristic of the industry, it would choose an opportunity that lies outside" (pg. 122, Ansoff, 1957). However, emerging trends in this market such as the encroachment of Original Equipment Manufacturers (OEM's) will begin to erode the position of even strong providers like Lufthansa, with Airbus already predicting $25 \%$ of its revenues to be generated by MRO sales by 2020 (Aviation Week, 2011).

The strategic benefits of diversification benefits can formally be broken down into the mitigation of financial risks, marketing power, and knowledge gain.

\subsection{Mitigation of financial risks}

The sharing of financial risk across a diversified corporate structure presents an additional positive aspect to this concept when applied in a controlled, related manner (Lubatkin and Rogers, 1989), due to the sharing of associated costs between business units. For example, much of the infrastructure required for cargo operations overlaps with those required for passenger transport, reducing the overall exposure to financial risk and investment, whilst collapsing operational costs over two revenue streams ${ }^{2}$. However, it has also been argued that such units may reduce risk by being responsible for their own P\&L (Lindstadt and Fauser, 2004, Taneja, 2004), due to the supposed greater duty of financial responsibility this places on each unit.

A useful case illustrating the strength of pursuing related supporting ventures such as MRO, Catering and Information Technology over units more subject to industry cyclicality, such as subsidiary airlines (as per Kilpi and Ari, 2004) is Swissair. Related diversification into lowmargin sectors, such as starting or purchasing other airlines may serve to "increase, rather than diversify risk" (Suen, 2002), as opposed to non-flying, high margin business units, which demonstrably serve to counter this, as can be inferred from Suen's analysis.

Suen (2002) comprehensively illustrates the manner in which Swissair's investment strategy was misguided with the assertion that SAirLines was grossly outperformed by its services divisions - comparing returns of $0.9 \%$ for SAirLines in 2000 versus a high of $32.4 \%$ for its cargo division SAirLogistics. The ability of its high-margin, non-flying subsidiaries to absorb financial risk is apparent from their EBIT between 1997 and 2000 - showing that non-flying divisions almost consistently delivered a greater combined result than the airline itself, culminating in an average earnings ratio of approximately 2:1 against passenger operations. Arguably, had the SAir Group focussed on these types of business, rather than investing in loss-making equity airline partners such as the chronically unprofitable Sabena, then it may

\footnotetext{
${ }^{2}$ Personal interview with Ram Menen, Divisional Senior Vice President, Emirates SkyCargo (retired).
} 
have been better positioned to respond to the spate of disasters that befell it between 1999 and 2001.

Looking towards the future, investment into middle-ground investments that may arguably straddle the fields of related and unrelated diversification within the air transport industry has not yet seen much academic discussion. Krishnan and Ellis (2008) note that Berkshire Hathaway serves as an example of a business with aviation interests that pursues a highly successful, yet largely unrelated investment strategy. They additionally argue that competent management can adapt to running any business. However, a criticism of this viewpoint could be seen in the fact that Berkshire Hathaway is specifically geared towards investment and has no central core proposition that necessitates support from its ventures. As such, any investment made is predicated solely on the basis of a tangible and expected financial return.

Conversely, analysis of Delta Airlines' investment into the Trainer Oil Refinery has yet to play out an either significantly positive or negative impact. Purchased for USD 150 million in 2012, the refinery had lost USD 136 million by mid-2013, however the correspondent drop in Delta's fuel price-per-gallon of 5.4\% and second quarter 2014 profits of USD 13 million (CNBC, 2013, CAPA, 2013) reveals potential for the investment, but it is crucial to note that profits must significantly improve to offset acquisition and initial loss expenditure. The facility's ability to service one of its primary strategic threats (the volatility of oil prices) could be seen as a long-term remedy for this. However, the argument could be made that Delta lacks the organisational competencies and infrastructure to mitigate the risk of investing in Trainer (a view espoused by former IATA CEO and Director General, Giovanni Bisignani $^{\mathbf{3}}$ ), despite Krishnan and Ellis' argument that good management could win out.

\subsection{Marketing power}

In contrast to Pakneiat et al. (2007), Aaker (1991) suggests that the establishment of a 'brand umbrella' allows firms to enter new markets more quickly regardless of a lack of prior expertise, with a reduction in risk due to the established strength of the central brand. Although it is important to note that the brand must possess widespread consumer familiarity, the associated benefits of an 'elastic' brand ${ }^{4}$ have allowed airline groups such as Virgin and Emirates to market a wide range of services based on a perception of 'prestige' (Park et al, 1986). Limits may be placed on the elasticity of a brand by consumer trends (Monga and John, 2010), resulting in a lifestyle brand being perceived as past its prime; however, the Virgin Group in particular has leveraged its brand equity to successfully sell into a range of sectors such as airlines, consumer retail, media and finance simultaneously, largely on the basis of positive brand perception (Pringle and Field, 2008). The positive aspects of diversification, regardless of whether it is related or unrelated, are ultimately connected with

\footnotetext{
${ }^{3}$ Personal interview with Giovanni Bisignani, former CEO and Director General, IATA.

${ }^{4}$ The American Marketing Association defines 'brand elasticity' the ability of a company's brand to 'stretch' to sell a diverse range of often unrelated products under the same marque. (AMA, 2010).
} 
the group's ability to project its brand across multiple sectors, consequently increasing consumer awareness.

Even the cessation of trading by the headline brand arguably did not harm many of the subbrands of the SAir Group, as can be seen in Figure 2 below. Many of Swissair's business units continue to be active in the marketplace, including Swissport, Gate Gourmet, Rail Gourmet, Balair (reorganised as Belair), Swissotel, SR Technics and Crossair (reorganised as Swiss International Air Lines).

Figure 2 SAir Group Structure circa 2001

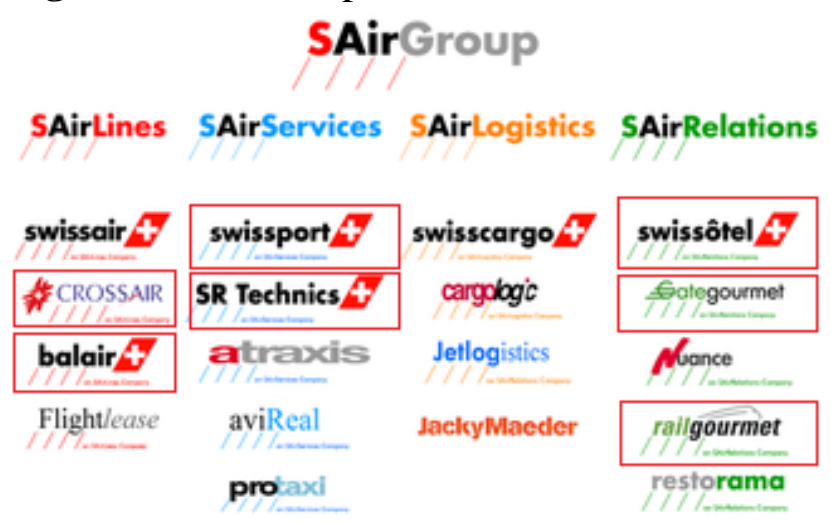

Source Adapted by author

Note: Still Active SAir Group Subsidiaries highlighted in red

It may be inferred from the example of the SAir Group that the often stronger earning potential of higher-margin, non-airline subsidiaries may provide greater benefits to the lowermargin airline itself, than vice versa. The integration of so-called "invisible assets" (Teece, Pisano, \& Shuen, 1997) refers to the intangible benefits reaped by marketing in a diversified business which lend themselves to the individual survival of SAir's units, not so much for their linkage to an admittedly tarnished brand, but due to their ability to leverage existing commercial and consumer relationships built under the group's original brand umbrella. Indeed, Suen (2002) argues that SAir's downfall was closely linked to its reliance on unprofitable airline equity partners, which drained cash and resources, limiting its ability to respond to external shocks. Conversely, the related supporting ventures within the SAir group acted as a strength, having "permeated its partners' operations", adding scale and external sales capability. Consumer perceptions of product quality may allow a firm to promote widespread usage of the core brand to generate awareness in related areas, further building brand equity and growing sales. Emirates' goal of establishing itself as a 'lifestyle brand' 5 would appear to support Suen's assertion about SAir Services in a modern context.

\footnotetext{
${ }^{5}$ Personal interview with Fabio Prestijacopo, Vice President Business Support \& DLM, Emirates Group.
} 


\subsection{Knowledge gain}

The ability for subsidiaries to inform learning across the business is made apparent by Heracleous et al's (Pg 38, 2004) assertion that Singapore Airlines (SIA) benefits from a notable "transfer of learning" between subsidiaries through staff job rotation. This encourages greater group-level oversight of the organisation, as opposed to business-unit level compartmentalisation. The net gain of employee competency and knowledge of multiple areas can be spread throughout the wider business. Support for this enhanced ability to inform the business' capabilities through cross-sharing of knowledge can be found in Day (1990), who defines the concept of corporate 'capabilities' as a "complex bundle of skills and accumulated knowledge that enable firms (or strategic business units) to coordinate activities and make use of their assets". As such, the greater a firm's ability to leverage knowledge gained through diversification, so too will follow its strategic capability to deal with a broader range of threats. If Porter's argument, that a company must 'relate to its environment' to flourish strategically, is applied to Heracleous (2004) and Day's (1990) assertions, then the intangible benefits of group-level knowledge gain must be viewed as particularly important in informing the positive aspects of adopting a diversified strategy.

There are also some key pitfalls related to following a diversification strategy. Jenkins et al's (2012) study of Air Asia refers to the concept of 'dominant logic' within a group as a driver of how it pursues its strategy of diversification. If a group's prevailing logic is geared towards taking a purely strategic approach to diversifying and supporting core competencies with relevant business units, then related diversification occurs as its default mode of strategic growth. However, when the dominant logic of a group is primarily 'philosophical' in nature (Pakneiat et al., 2010) and diversification is approached on the basis of pursuing growth opportunities for financial returns regardless of sector, then whilst general capabilities and knowledge may grow, the ability to leverage centralised strategic gains does not - resulting in unrelated diversification.

Where errant corporate logic is present, a firm's need to diversify may be ill-informed or unable to adapt to rapidly changing market conditions. This in effect mirrors the stock-market concept of a 'value trap', whereby an investment may appear to be sound in isolation, but can prove toxic to a portfolio due to consistent underperformance, or in this case its inability to aid the business in relating to its marketplace, as per Porter. Ansoff also supports this notion, arguing that companies may generate new competition through diversification from strong incumbents that it is underequipped to counter.

\section{Data sources and methods}

Two case study airline groups Lufthansa and Emirates were selected for strategic and financial assessment on the basis that both are well established conglomerates that could possibly act as a blueprint for other carriers considering diversification as a strategy. Through the use of a number of commonly used strategic analysis tools the two Groups' diversified 
businesses could be compared in order generate recommendations for a uniform or a nonuniform approach to vertical integration. The Strategic Scoring Method, employed for this study was based upon a selected series of strategic and financial criteria employing qualifiable insights as referenced against the BCG and SWOT matrices. One overall business unit ranking based on an average composite of standardised factors was then determined.

It was intended to be primarily allegorical and illustrative, producing an 'Indicative Result' that was subsequently analysed and critiqued. The majority of factors were quantitative, with a number of qualitative exceptions, which are based on clear statements of fact drawn from industry reports and expert interviews exclusive to this study. Each business unit analysis in section 4 is presented with a summary table, showing an Average Score and Indicative Result $^{6}$. Using the example of LSG SkyChefs, the way the strategic scoring system works at the business unit level is shown below in Table 3.

Table 3 LSG SkyChefs Scoring Table

\begin{tabular}{|c|c|c|c|c|}
\hline LSG SkyChefs & Underachiever & $\begin{array}{l}\text { Weak } \\
\text { Performer }\end{array}$ & $\begin{array}{l}\text { Strong } \\
\text { Performer }\end{array}$ & Best in class \\
\hline $\begin{array}{l}\text { Parent } \\
\text { company } \\
\text { revenue growth } \\
\text { (avg. 2009- } \\
\text { 2014) }\end{array}$ & Negative to $5 \%$ & $6-10 \%$ & $11-20 \%$ & $21-30 \%+$ \\
\hline $\begin{array}{l}\text { Parent } \\
\text { company profit } \\
\text { growth (avg. } \\
\text { 2009-2014) }\end{array}$ & Negative to $5 \%$ & $6-10 \%$ & $11-20 \%$ & $21-30 \%+$ \\
\hline $\begin{array}{l}\text { Business Unit } \\
\text { revenue growth } \\
\text { (YOY) }\end{array}$ & Negative to $5 \%$ & $6-10 \%$ & $11-20 \%$ & $21-30 \%+$ \\
\hline $\begin{array}{l}\text { Business unit } \\
\text { market share }\end{array}$ & $0-5 \%$ & $6-10 \%$ & $11-15 \%$ & $16-20 \%+$ \\
\hline BCG Position & Dog & Question Mark & Cash Cow & Star \\
\hline $\begin{array}{l}\text { Historical } \\
\text { market growth }\end{array}$ & Less than $0-5 \%$ & $6-10 \%$ & $11-15 \%$ & $16-20 \%+$ \\
\hline Market outlook & Weak & Fairly weak & Fairly positive & Positive \\
\hline $\begin{array}{l}\text { Number of } \\
\text { strategic } \\
\text { options } \\
\text { available }\end{array}$ & 0 & 1 & 2 & 3 \\
\hline Average score & \multicolumn{4}{|c|}{2.6} \\
\hline $\begin{array}{l}\text { Indicative } \\
\text { result }\end{array}$ & $\begin{array}{l}1 \text { Consider resale or } \\
\text { restructure }\end{array}$ & $\begin{array}{l}2 \text { Retain and } \\
\text { review }\end{array}$ & $\begin{array}{l}3 \text { Invest in BU } \\
\text { and build value }\end{array}$ & $\begin{array}{l}4 \text { Divest or } \\
\text { leverage }\end{array}$ \\
\hline
\end{tabular}

The factors measured are informed by the following criteria:

\footnotetext{
${ }^{6}$ Full tables showing all business units can be made available upon request to the corresponding author frankie.oconnell@cranfield.ac.uk.
} 
- Parent Company Revenue Growth is taken as an average. Neither Lufthansa Group or Emirates Group achieved higher than 30\% year-on-year growth, hence the capping of this scale at $30 \%$. Revenue is used as a proxy for the earnings potential of the parent and as such the cash resources available to its Business Units.

- Parent Company Profit Growth follows an identical logic. Profit is employed as a proxy for assessing the viability of the parent and as such, the stability of the Business Unit's position in the group (e.g. weak profits may incentivise the parent to sell Business Units).

- BU Revenue Growth indicates the trend followed by the business unit and its base financial value to the group. A figure for Profit is not included as this is not published by the Emirates Group, so it would not be possible to standardise with Lufthansa Group results.

- BU Market share illustrates the Business Unit's strength in its respective market.

- BCG Position further underpins BU market share by noting the combination of relative market share and market growth to find its overall positioning in the market, as per BCG matrix rankings (Dog, Star, etc.).

- Historical Market Growth observes the trend followed by the market in which the Business Unit operates.

- Market Outlook accounts for the potential of the business unit, which is based on whether the market that the business unit operates in is expected to grow, contract or remain static. This serves to underwrite the 'Parent Profit Growth' metric in assessing future prospects.

- Strategic Options Available relates to the number of Strategic Options identified by the Ansoff matrix as areas for potential development - a low number of options may indicate a business unit with little potential for growth.

- Average Score denotes the average of the above rankings to provide a final positioning.

- The Indicative Result category is adapted from the options found in the BCG matrix ('Product Development', 'Divestment', et al) to provide a notional understanding of the business unit's strategic value

Interviews were conducted with a mix of experts from inside and outside the two selected Airline Groups all of which were carried out in the year 2014. They were open ended, semistructured interviews that were carried out face-to-face and over the phone. The intended purpose of the interviews was to provide an enhanced narrative to the financial and strategic numerical data on the two airline conglomerates. As such, key excerpts from the interviews are located across sections 2 to 6 in support of or in contrast to literature and data obtained from secondary sources. 


\section{Overview and business trend analysis}

\subsection{Lufthansa Group}

The Lufthansa Group operates under a relatively simple structure, with the overall group being constituted of five main 'business segments': Passenger (relating solely to the passenger carrying activities of Lufthansa airlines, excluding ventures such as Germanwings), Logistics (cargo), Technik (maintenance), IT Services and LSG SkyChefs (catering). Each reportable segment operates as a standalone $P \& L$ centre, with detailed results of revenue (both 'internal' - i.e. revenue gained from servicing clients within the Group - and 'external', accounting for third party work), capital expenditure, profit, operating margins and employee strength being published.

Comparative analysis of Lufthansa's business units has been benchmarked against performance figures for its core Passenger division, which accounts for the dominant share of group revenue (Figure 3 below). As the group's largest operational entity, Passenger can serve as a bellwether for tracking Lufthansa's fortunes against the wider market.

Additionally, the Group's business units are dependent on both the airline's fortunes and the wider market as a measure of demand for their services, given that they tender for contracts on a competitive basis both within and outside of the Lufthansa Group ${ }^{7}$.

Figure 3 Lufthansa Group BU Revenue Contributions

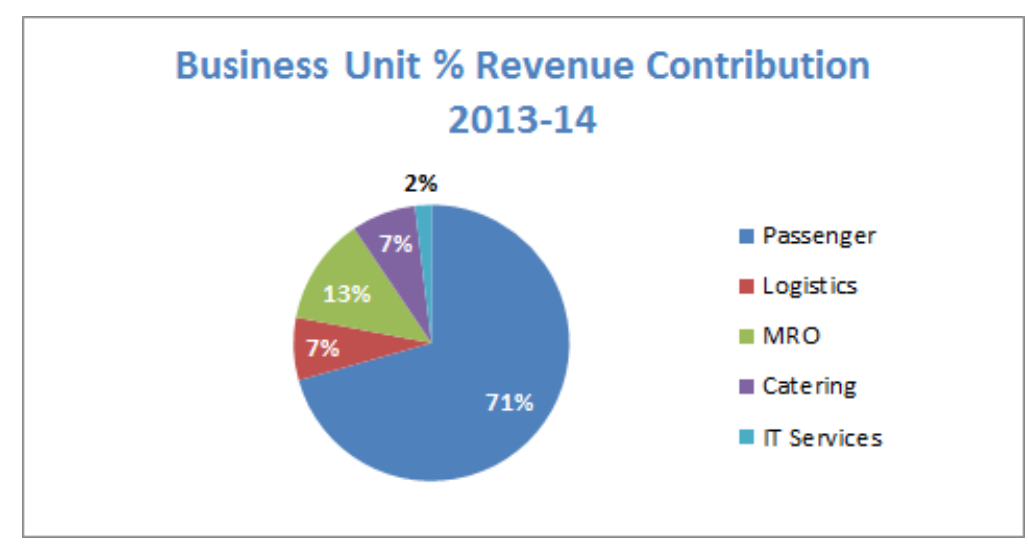

Source Adapted from LH Group Annual Report 2013-2014

Measures of productivity employed in the following analysis are largely centred on the split between internal and external revenue delivered by business units, operating profit margins and employee productivity. All of these factors are compared to Passenger division results to show the degree to which Lufthansa Group's business units are able to offset weak trading in the group's core competency, as well as demonstrate their generally stronger earning potential.

Although it is important to note that these business units would likely not exist without the Passenger division, they do not draw the majority of their revenue from servicing it.

\footnotetext{
${ }^{7}$ Personal interview with Harald Heppner, Manager Corporate Strategy - Lufthansa Group.
} 
Comparative analysis of business units highlights areas of strong performance and a general trend for higher margins over Lufthansa's core passenger business, as seen in Figure 4 and Table 4:

Figure 4 LH Group Comparative Operating Margins 2009 - 2014

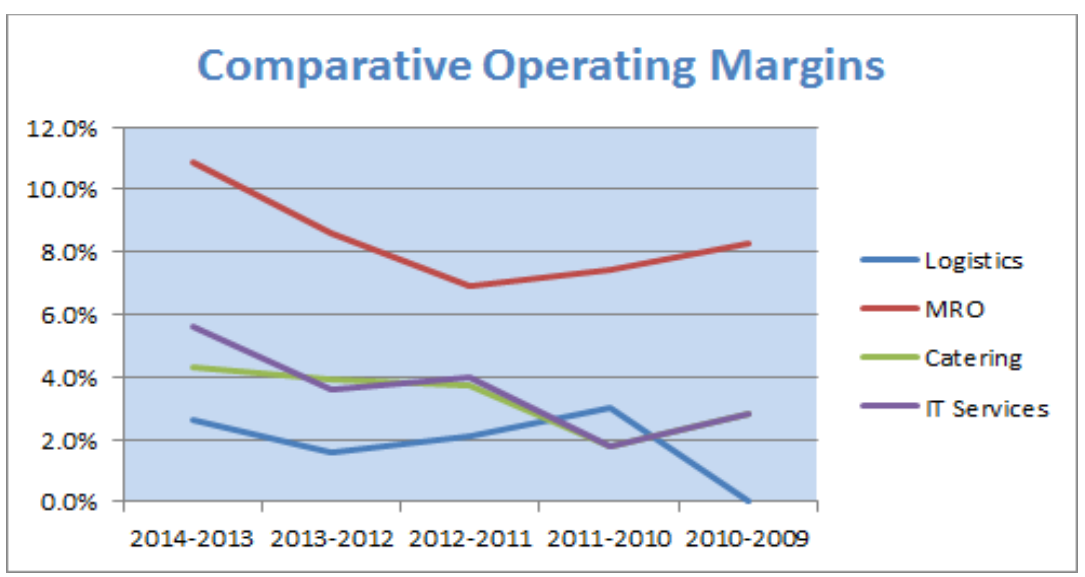

Table 4 LH Group Comparative Average Operating Margins 2009-2014

\begin{tabular}{|l|l|}
\hline Passengers & $1.9 \%$ \\
\hline Logistics & $1.9 \%$ \\
\hline MRO & $8.4 \%$ \\
\hline Catering & $3.3 \%$ \\
\hline IT & $3.6 \%$ \\
\hline
\end{tabular}

Source(s) Adapted from LH Group Annual Reports 2013-2014

MRO initially appears to be particularly strong, but further analysis in section 4.1.2 illustrates the underlying factors that may suggest its future could be in doubt. Indeed, headline figures for all revenue contributions require closer analysis. Whereas Figure 5 (below) may show Logistics to have the highest percentage of external revenue (99\%), it is important to note that this is achieved by default, as Logistics lacks internal trading partners. This is followed by LSG SkyChefs at 76\%, which possesses a dominantly outward-looking revenue stream and a fairly static overall revenue contribution. Conversely, MRO and IT's ability to balance internal and external revenue, with a trend towards external growth in each demonstrates they have high growth potential as standalone units, with a bias towards financial rather than purely strategic. 
Figure 5 LH Group External Revenue as \%

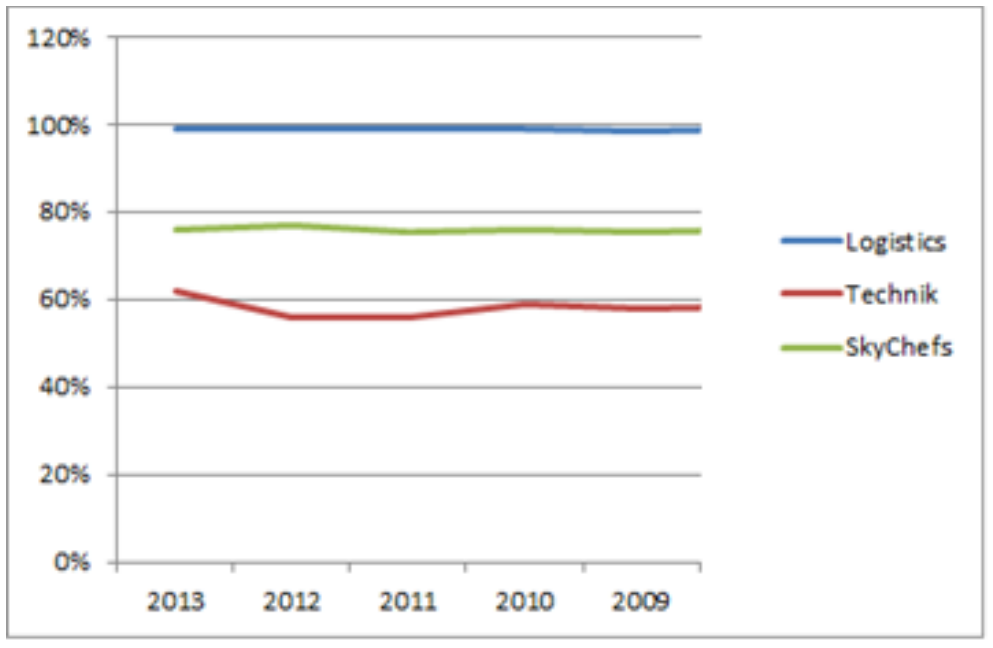

Source Adapted from LH Group Annual Reports 2009-2014

\subsection{1 - Logistics: Business Trends Analysis}

Cargo presents a mix of fortunes for any airline group, Laurie Berryman, Vice President UK, Emirates Airline, asserts that it is arguably one of the only diversified revenue streams available to airlines "by default". Harald Heppner, Manager Corporate Strategy, Lufthansa, agrees, noting that cargo is an "in-built, ready-to-use asset". The ability to enter the cargo market is available by virtue of already possessing bellyhold capacity that would otherwise be left solely for baggage or mail transport. In spite of this low initial barrier-to-entry, it is also a notoriously challenging sector, particularly due to its sharing of fuel cost with passenger operations (Holloway, 2008). Although this has the potential to cross-subsidise operations in both areas, inefficiencies inherent to the cargo arena can be difficult to overcome. Flexibility may be built into the model by introducing pure-freighter aircraft to offset gaps in the passenger network (Flight Global, 2013), but the costs of freighter introduction and operation often outweigh the benefits of leveraging bellyhold capacity if operational scale is insufficient (Morrell, 2007).

Global cargo market downturn towards 2011-2012 (Flight Global, 2013) has seen Logistics' operating margin collapse from a 2010 high of $11.4 \%$ to a 2009 low of $-8 \%$; both the respective highest and lowest of any Lufthansa Group business units. Despite scaling back pure-freighter growth plans (Flight Global, 2013), revenues recovered in 2013 to gain USD 500 million on 2009 levels, however this is still a decrease year-on-year versus 2012 (USD 3.49bn) and 2011(USD 3.9bn). A side benefit of this could be seen in the elimination of competitors, particularly in the pure-freight arena, where Air France/KLM has withdrawn the majority of its fleet (CAPA, 2013), although this has also benefited fast-growing competitors in the Arabian Gulf.

The Logistics' margin growth figures noted in Table 4 indicate that negative revenue growth (Figure 6 below) has in fact been outstripped by negative margin growth, combined with negative employee growth - which suggests an organisation becoming progressively more 
inefficient year-on-year. This is further compounded by 2014 revenues outstripping those of competitor Emirates by USD200 million. Although it was able to generate more revenue on fewer FTK's (Freight Tonne Kilometers) than Emirates - with 278,528,303 to Emirates' $337,219,971$ (CAPA, 2014) - this is not necessarily indicative of wider efficiencies. When its negative profit-to-negative-revenue-growth is considered, Logistics ability to deliver margins arguably fails to overcome this small bonus.

Figure 6 Logistics Revenue Trend $2009-2014^{8}$

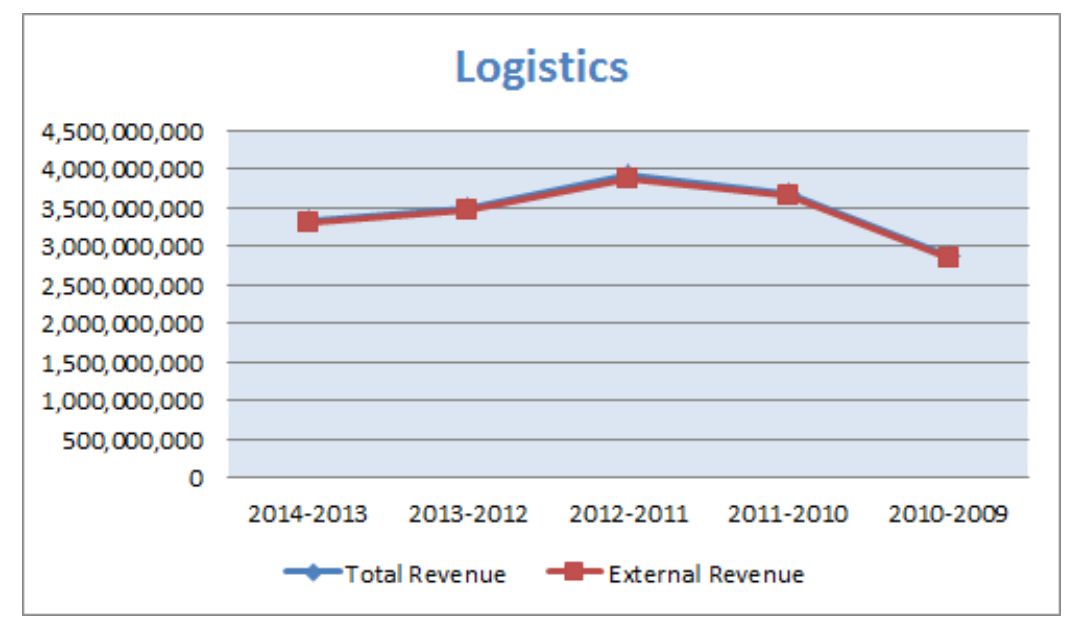

Source Adapted from LH Group Annual Reports 2009-2014

Although Logistics is presently seeing a downturn and is subject to a high degree of cyclicality, it is nevertheless able to deliver benefits to the wider group even when its own financial prospects are challenged - this demonstrates a particular strength of diversification. IATA noted moderate growth of $1.8 \%$ in the cargo market in 2013, with the trend expected to continue into 2014 (IATA, 2014). As such, although the cargo market is currently weak, Logistics' cost cutting should position it well to capitalise on a sector predicted to rebound. Below is a SWOT summary for Lufthansa Logistics (Table 5).

Table 5 Logistics SWOT summary

\begin{tabular}{|l|l|}
\hline Strengths & Weaknesses \\
\hline $\begin{array}{l}\text { Economies of scope with passenger network } \\
\text { (broad bellyhold network) }\end{array}$ & Poor profit margins \\
\cline { 2 - 2 } Cash cow market position & High overheads of pure freighter fleet \\
\hline Opportunities & High capital expenditure \\
\hline $\begin{array}{l}\text { Cargo downturn has eliminated some } \\
\text { competitors }\end{array}$ & Threats \\
\hline Freighter re-fleeting programme & Weak global cargo market \\
\hline
\end{tabular}

\footnotetext{
${ }^{8}$ Logistics External Revenue (USD 3,423,850,000) contributes 99\% of Total Revenue (USD 3,457,416,000).
} 


\subsubsection{Technik: Business Trends Analysis}

Despite producing healthy results and a proven ability to offset losses made by other divisions, analysis of wider industry trends indicates attractiveness of the MRO sector may be subject to erosion. Mr. Heppner notes the cost-effectiveness of in-house solutions from airframe and engine manufacturers (OEM's) presents an attractive prospect to customers, due to an in-house MRO's natural fit within its value chain. Indeed, OEM's consequently achieve "double digit" margins, versus an MRO industry average of 7\%. When viewed against the trend of negative airline profitability (Aviation Week, May 2013), the lower-cost alternative of OEM's in the space traditionally occupied by companies such as Technik will serve as a growing cause of concern for the Lufthansa Group. This is highlighted by the fact that over $80 \%$ of customers for General Electric's 'LEAP' geared turbofan engines have purchased 'TotalCare' packages, providing lifetime care for maintenance and spare parts, bypassing MRO's. Indeed Chris Doan, CEO of consultancy, TeamSAI expects OEM to achieve "overwhelming mastery of the market" in the near-term (AFM, 2013, FlightGlobal, 2011).

Within this sphere, a natural alliance between OEM's and independent MRO providers may develop, with a strong potential for marrying the "intellectual property" required for spare part manufacturing of the OEM to the "local knowledge" of MRO's (Aviation Week, Nov 2012). This ultimately serves to squeeze providers like Technik in the middle. The threat to Technik here may be inferred as an erosion of its ability to provide an end-to-end service to clients that is competitive in both price and global reach against OEM / independent jointventures.

Technik's reliance on volume of checks performed to inform the scale of its business (Aviation Week, May 2012) allows it to realise strong profits. However, its status as a 'major' purchaser of OEM aftermarket equipment does simultaneously fuel its main competitors' revenues. Over time, it is arguable that this will contribute to thinning margins, as OEM's grow in stature. Technik aims to negotiate access to OEM intellectual property and ultimately begin fabricating components itself. If successful, then it may be able to sustain its present market position, but this does represent its only major tactic to mitigate the growing OEM presence. However, if it fails in this objective, then Walter Heerdt, SVP of Marketing \& Sales for Technik notes that the setback would be "difficult to overcome" (Aviation Week, May 2012) - suggesting steadily worsening prospects for Technik's viability in a fastchanging MRO landscape.

MRO contributes the healthiest operating margins within the Lufthansa Group, averaging $8.4 \%$ between 2009 and 2013, comfortably more than double the five year averages for all other business units, including passenger. It is also one of the most consistent performers in terms of margin growth (Figure 7 below), showing a dip following cuts made in 2009, but recovering towards 2013. Technik's strong results may be illustrated by its operating profit in 2013, which matched $81 \%$ of the Passenger division's own profit. Similarly, in 2011 Passenger made a non-proportional inverse $81 \%$ of Technik's operating profit. 
Figure 7 Technik Operating Margin

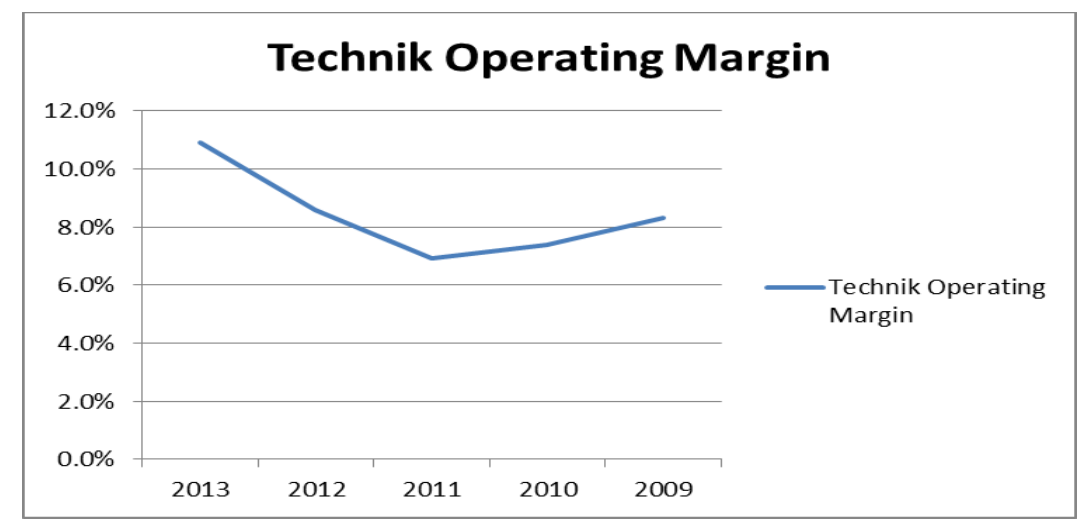

Source Adapted from LH Group Annual Reports 2009-2014

Figure 8 Technik Revenue

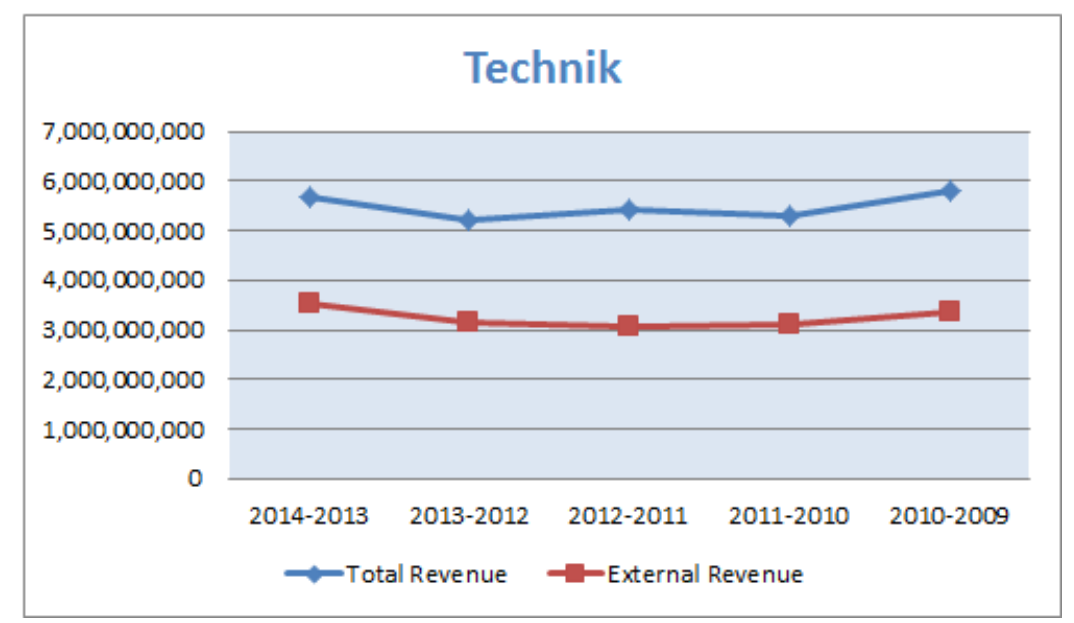

Source Adapted from LH Group Annual Reports 2009-2014

Technik requires a relatively low capital expenditure versus revenues, averaging USD 160 million from 2014 to 2009, although it is worth noting that much of its assets - particularly facilities - are grandfathered and as such, amortised over a long period of time. As such, these low legacy costs position Technik as a solid investment for the Lufthansa Group. However, it is arguable that the capital costs for any other carrier wishing to move into this sector for the first time would be very high (Flight Global, 2011), negating the benefits currently seen by Lufthansa. The case may be that MRO is a strong sector for businesses with existing operations, but the financial barriers to entry are high, dampening the potentially solid margins it is capable of achieving otherwise.

It is also an employee-intensive operation, requiring 20,000 staff - which despite being less than half of Passenger's requirements, does still show that it has the second lowest productivity-per-employee rate within Lufthansa Group. This is exacerbated by a costly, entrenched union structure (Irish Independent, 2013), which when combined with the OEM dilemma, may play their part in reducing the attractiveness of Technik as an investable asset in the long term. These strategic points are summarised below in Table 6 . 
Table 6 Technik SWOT summary

\begin{tabular}{|l|l|}
\hline Strengths & Weaknesses \\
\hline High margins relative to Group average & Employee intensive \\
\hline Limited legacy costs & High average wages \\
\hline Resilience against external shocks & Low margins relative to OEMs \\
\hline Opportunities & Threats \\
\hline Potential to partner with OEMs & Encroachment of OEMs in MRO market \\
\hline Acquisition of intellectual property & Failure to acquire 'intellectual property' \\
\hline
\end{tabular}

\subsubsection{LSG SkyChefs: Business Trends Analysis}

Much of SkyChefs' currently robust financial position was foreshadowed by results leading up to 2010, with operating profit and revenue increasing year-on-year (8\% and $2 \%$ respectively) - however the impact of Lufthansa's cost-cutting programme (known as 'SCORE') on SkyChefs' becomes apparent when it is considered that 2010's operating margin and operating profit were decreasing significantly as costs and revenue increased. As such, the efficiency gains seen are tangible and indicative of a company now operating in a more competitive manner. Mr. Heppner notes that SkyChefs' is "required to competitively bid for all Lufthansa Group business, nothing is taken as given", with an average of $76 \%$ of its revenue generated externally (Figure 9 below), showing no reliance on Passenger operations to generate business. It may be reasonable to infer that in light of Lufthansa's continued need for cost cutting, SkyChefs' need to win Group business by being the lowest bidder (and therefore depressing yields) may not always be in the Group's best interest, if it can instead generate stronger returns from winning external business.

Figure 9 SkyChefs Revenue

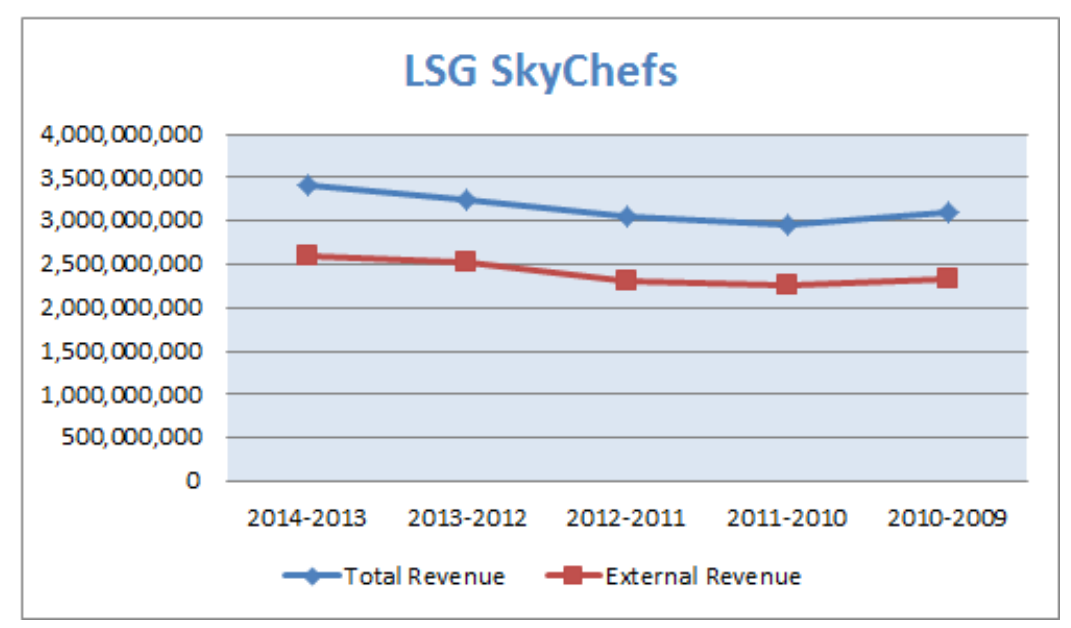

Source Adapted from LH Group Annual Reports 2009-2014

Ultimately, despite LSG's market leading position ${ }^{9}$ Lufthansa Group has investigated options for divestment - initially in 2012, with no success in securing a bidder. Morgan Stanley notes

\footnotetext{
${ }^{9}$ LSG SkyChefs is the single largest airline catering business, accounting for $30 \%$ of the global marketplace worth up to USD11 billion (LSG SkyChefs, 2014).
} 
that Lufthansa views SkyChefs' as 'non-core' - and that an increasing appetite for consolidation in the catering market was likely to push Lufthansa towards sale (Morgan Stanley, 2012). Following the divestment of unprofitable subsidiaries as part of the SCORE programme (e.g. BMI British Midland), the Group turned its attention to the sale of profitable assets, as part of a broader strategy to realign its core competencies (DW/Reuters, 2012). Indeed, a potential bidder for the business emerged in the Emirates Group, which has remained open to purchasing the business should it be offered again (Bloomberg, 2013).

The sale of a profitable, market leading business unit to a primary competitor could be observed as a strategic threat to the Lufthansa Group. However, it could also represent a significant opportunity due to the potential for Lufthansa Group to sell SkyChefs at a time of predicted market growth, ${ }^{10}$ maximising the sale value of the business unit. Equally, Lufthansa Group could miss out on the opportunity to retain a newly cost-efficient, market leading business unit poised to deliver strong returns.

Although employee numbers have increased by 4,000 from 28,000 in 2009 to circa 32,000 in 2013, initially suggesting cost inflation, measurement against operating profit and total revenue shows increasing productivity. This is particularly impressive when viewed against the fact that comparisons with previous years are not like-for-like; with 2013 showing a greater operating profit per employee than 2012, concurrent to an increase in operating margin of $0.4 \%$ despite adding 2,000 employees to the business.

Although these gains are not significant, it shows that SkyChefs has controlled costs whilst expanding revenues, driving investment (capital expenditure increased significantly in 2013 versus previous years) and headcount, falling into line with SCORE's stated objective of maximising value 'at all suppliers' (LH SCORE Expert Session, 2013), specifically including internal suppliers.

SkyChefs has a large global presence and often operates in regions where Lufthansa has no passenger division presence. The benefits of SkyChefs' high degree of independence can be seen in its financial results, with growth in operating results outstripping revenue growth between 2013 and 2009, despite mixed results for its parent company during that period. Although it has been subject to the SCORE programme, its ability to independently control costs has allowed it to nuance its approach and deliver progressively greater financial value to its parent (See Table 7 for a SkyChef SWOT summary).

\footnotetext{
${ }^{10}$ The global catering market is set to grow explosively - up to USD16.5 billion by 2016, counteracting several years of static and negative growth. Despite growth in passenger numbers, catering spend has remained static, due to airline budget cuts (PRWeb, 2013).
} 
Table 7 SkyChefs SWOT summary

\begin{tabular}{|l|l|}
\hline Strengths & Weaknesses \\
\hline Market leader & Servicing parent company not guaranteed \\
\hline Largely independent of LH for revenues & Weak market (at present) \\
\hline Economies of scope with LH group & Manpower intensive business \\
\hline Opportunities & Threats \\
\hline Strong market growth predicted & Divestment strongly considered by parent \\
\hline $\begin{array}{l}\text { Ability to service clients throughout the LH } \\
\text { Group }\end{array}$ & Growth of new suppliers \\
\hline
\end{tabular}

\subsection{Emirates Group}

In order to assess Emirates' diversification strategy, the structure of how results are accounted for within the Emirates Group must be clearly understood. Ram Menen, the retired founding executive of Emirates SkyCargo notes the Emirates Group has "a very different model", with revenue being generated by two distinct entities: Emirates Airline and Dnata. Both entities share common Finance, IT and Human Resources to generate economies of scope. Functions such as Finance and IT are administered as part of Dnata, but act on behalf of the entire group. A simplified visual interpretation of how the business units of Emirates Group are structured can be seen in Figure 10.

Figure 10 Emirates Group Business Units - Lines of Reporting

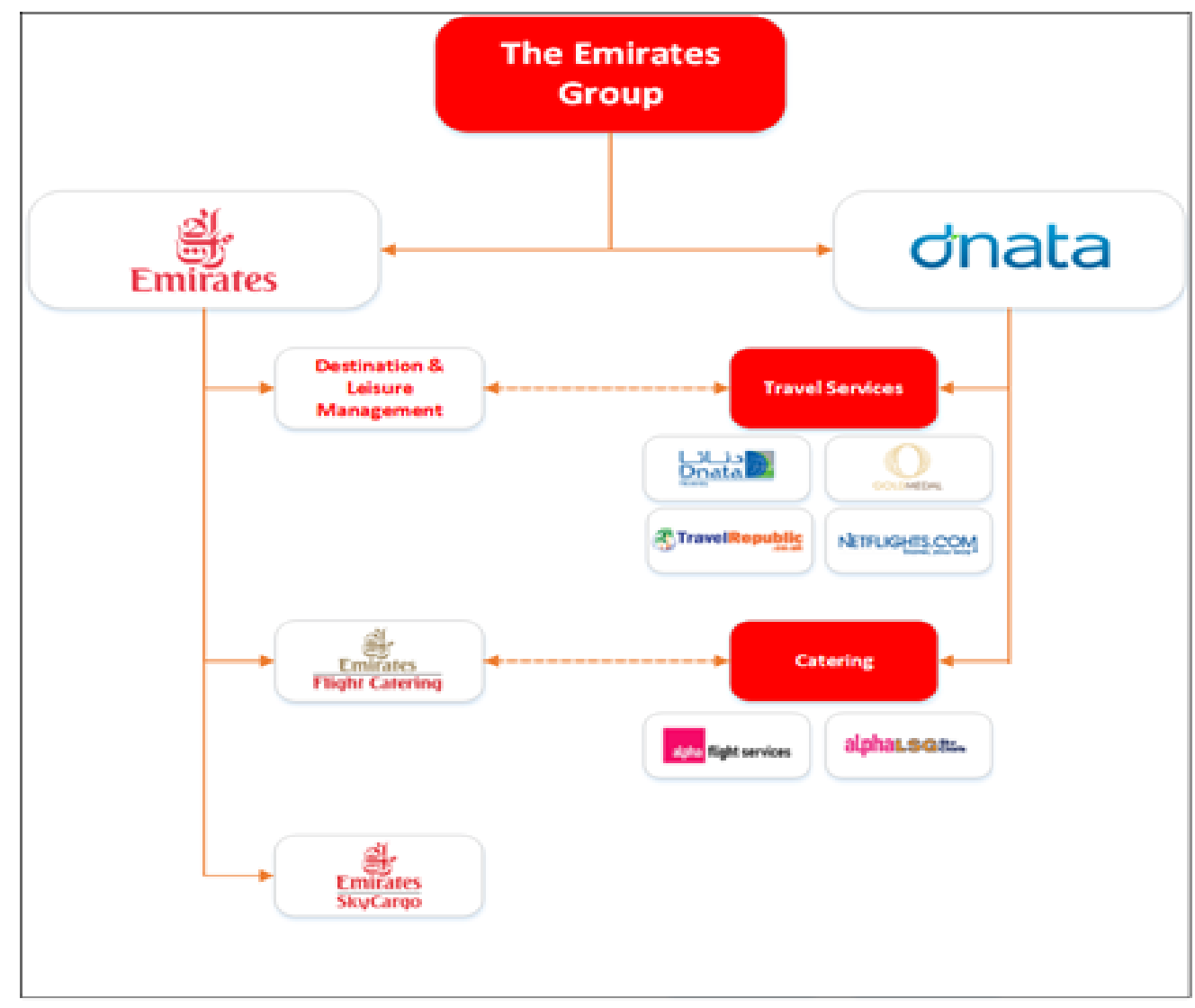

Source Authors, derived from Emirates Group Annual Reports, 2009-2014 
Some revenue streams report under Dnata exclusively, or jointly between Emirates Airline and Dnata (Destination \& Leisure Management and Travel Services), depending on their degree of interface with the passenger airline business. For example, within the Emirates Group, both Emirates Airline and Dnata operate travel businesses, noted as 'Destination \& Leisure Management (DLM)' by the airline and 'Travel Services' by Dnata. However, both areas perform very similar functions, with those under the airline umbrella servicing its specific needs more closely and those under Dnata providing services to a wider range of clients. As such, this section analyses DLM and Travel Services and other such overlaps as one overall area contributing a net benefit to the Emirates Group as a whole.

Benchmarking of Emirates Group results presents a different challenge to analysis of Lufthansa Group by virtue of the complexity of its organisational structure and less comprehensive financial reporting. No in-depth financial statistics on individual business units are published, despite operating them as P\&L centres. Instead reporting is limited to evaluating Group level performance, with additional commentary on the revenue contributions of its business units. This absence of published operating ratios for business units limits comparison with Passenger division results (as per Lufthansa Group's methodology), as revenue alone does not offer insight into the strategic benefit delivered by each unit to the Group.

To generate insight into Emirates' strategy and the trends it is subject to, this section explains relationships between Group business units and their role in driving the Group. Revenue generation will be utilised as a KPI for each unit, cross-referenced against personal interviews conducted with senior executives across the Emirates Group to form a picture of both their performance and strategic value to the Group.

The overall split in revenue between Emirates Airline and Dnata within the group is heavily weighted towards Emirates, with Dnata accounting for an average of $8 \%$ of Group revenues between 2009 and 2014 (Figures 11 and 12). However, Dnata's profit margin is on average more than double Emirates Airline's, at 14\% versus 5.7\% (Emirates Financial Reports, 2009 $-2014)$.

Figure 11 Emirates Group Revenue Contributions

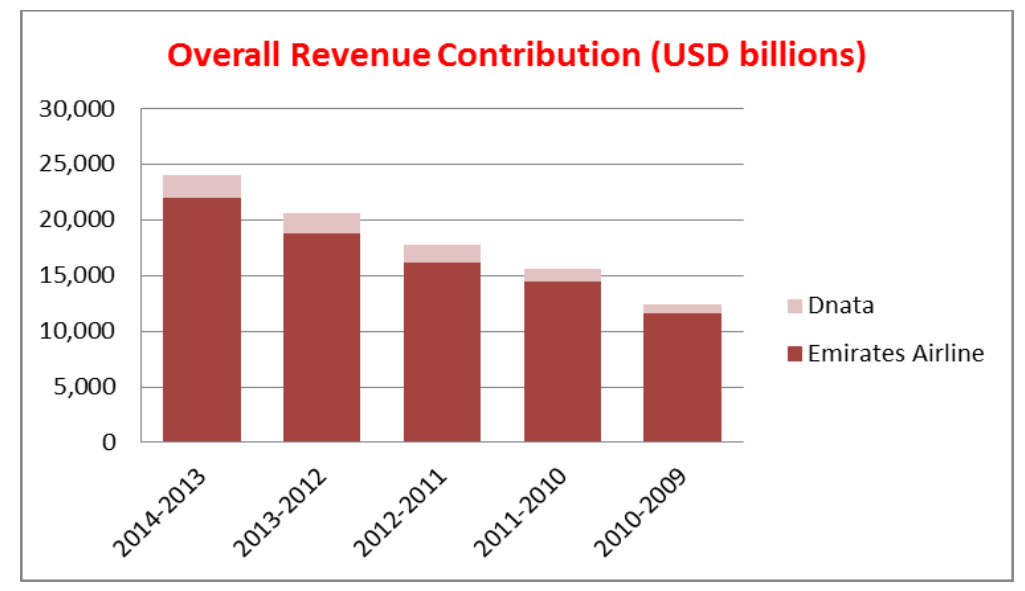


Figure 12 Emirates Group Comparative Margins

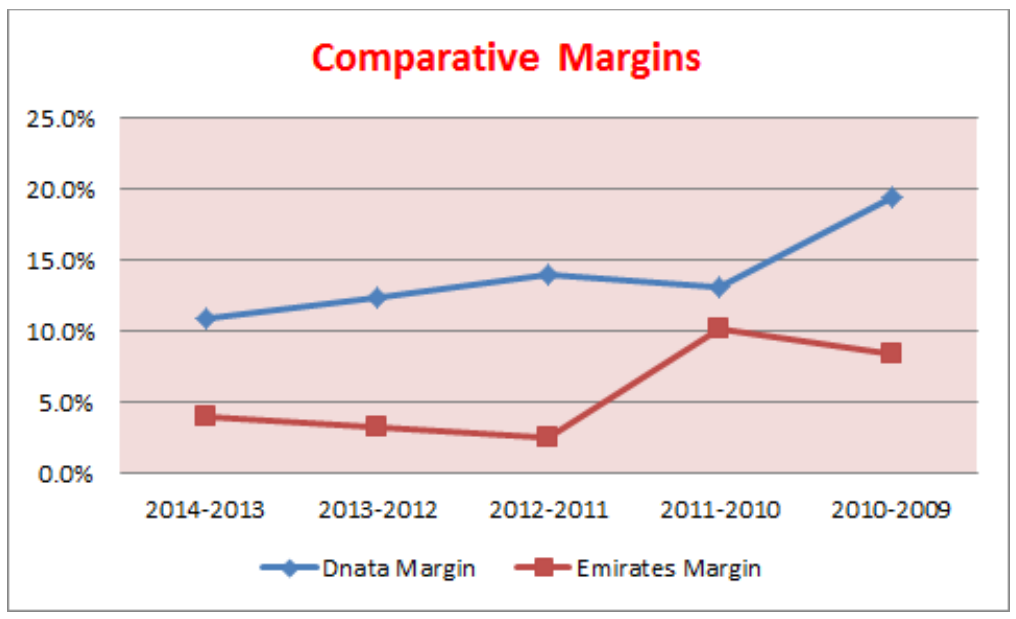

Source Adapted from Emirates Group Annual Reports 2009-2014

Such margins are particularly impressive when it is considered that up to $40 \%$ of Dnata's workforce is based outside of the UAE (Emirates Group Annual Report, 2014), where labour cost is one of the core drivers of the Emirates Group's cost advantage (CAPA, 2014).

Additionally, the intangible contribution of Dnata's service divisions to Emirates Airline's bottom line cannot be underestimated, with the carrier dependent on much of the infrastructure it provides, despite not having to directly bear the cost of their operation arguably distorting the picture. It may not be unreasonable to infer that this crossfunctionality, combined with the healthier margins of Dnata as a whole present an attractive case for diversification within the Emirates Group, with a greater bias towards strategic value, rather than the financial bias evident within Lufthansa.

\subsubsection{SkyCargo: Business Trends Analysis}

Emirates' SkyCargo division has achieved the remarkable feat of expanding its business in a shrinking global freight market, achieving growth "against the industry norm" (SkyCargo, 2014). In 2014 it delivered $15 \%$ of group transport revenues with a total uplift of 2.3 million tonnes of cargo in (Emirates Annual Reports 2009 - 2014), comfortably remaining the Emirates Group's largest non-core business unit as well as the world's largest cargo airline by available freight tonne kilometres (CAPA, 2014).

SkyCargo has largely grown through the natural introduction of bellyhold capacity from Emirates Airline's passenger growth, as well as utilising pure freighters ${ }^{11}$. The freighters in particular provided what Mr. Menen calls a "clear and independent distribution capability" with which to significantly grow the business at a time when other airlines have been reducing freighter fleets. He also points out that this independence is seen in SkyCargo being granted full P\&L on freighter operations and a remit to operate as "an airline within an airline", driving efficiency.

\footnotetext{
${ }^{11}$ Freighters are operated as a mix of wholly-owned or leased aircraft (Boeing 777-200LRF) and wet-leased Boeing 747-400ERF's on Aircraft, Crew, Maintenance \& Insurance (ACMI) contracts originally from Atlas Air and later, TNT Airways (TNT Airways, 2012 / Airline Cargo Management, 2013).
} 
Mr. Menen looks to 'speed' as a core strength, believing that in the time-sensitive arena of global logistics, whenever speed is lost, cost creep sets in and competitive advantage is lost. This underpins the strategic nature of Emirates' investment in the SkyCargo business, which despite delivering large volumes of revenue to the Group in its own right, is also key to aiding the justification of the passenger route network. Mr Berryman notes the "significant added value" of cargo operations to passenger routes due to its ability to provide a more dynamic product mix at a limited increase in cost-of-sale.

The Group's strategy of centralising core-functions enabled Mr. Menen and his team the "freedom" to significantly reduce cost, expedite decision times and attain the speed-to-market necessary to outmanoeuvre competitors. SkyCargo often competes for group financial resources, with the company noting that "Emirates' management monitors the operating results of its business units for the purpose of making decisions about resource allocation" (Emirates Group Annual Report, 2014)

Mr. Menen argues that instead of hampering progress, the need to propose a robust case to compete for resources has strengthened the analytical capability of Emirates' divisions enhancing their business acumen (a form of 'knowledge gain', as discussed in section 2), which he believes sees significant transfer to other commercial processes within the division, resulting in a more effectively run overall business.

This analytical nous and quick speed-to-market has seen revenues increase from USD1.8bn to USD3bn. Further to this, since the division's inception in 1985, revenues have grown from 10,000 tonnes of freight (SkyCargo.com, 2009) to 2.5 million tonnes carried (Emirates Group Annual Report, 2014). Average year-on-year growth stands at approximately $13 \%$ between 2009 and 2014, with the most significant growth occurring between 2009 and 2010 at 27\%, versus $8 \%$ for most other years (Figure 13). This leap in earnings can be attributed to the introduction of the Boeing 777-200LRF pure freighter in March 2009 (SkyCargo.com, 2009).

Figure 13 SkyCargo Revenue

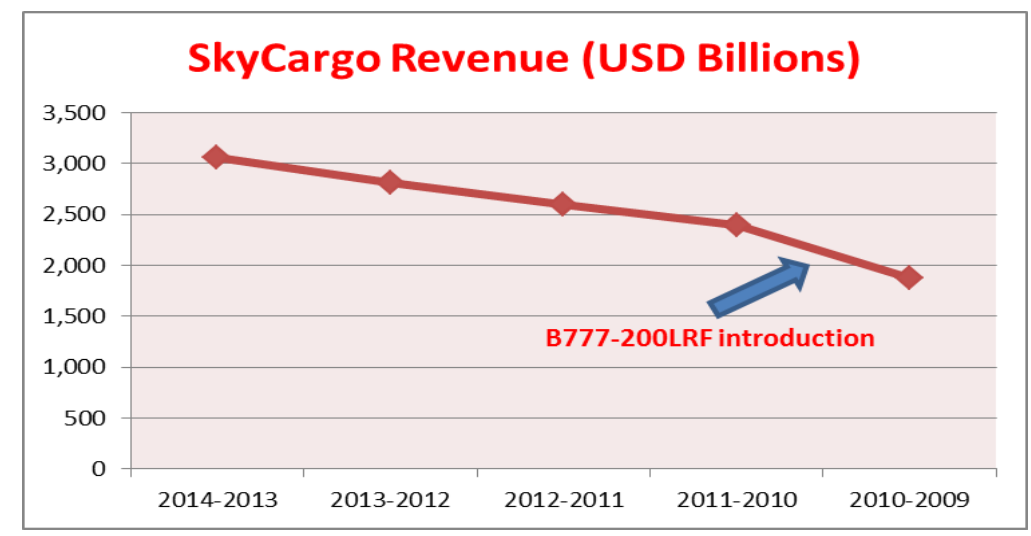

Source Adapted from EK Group Annual Reports 2009-2014

SkyCargo's dependence on Emirates Airlines' bellyhold capacity - which accounts for 74.8\% of total cargo tonnage capability, can present drawbacks. The relative tonnage gap (35\%) 
between an Airbus A380-800 versus the longer Boeing 777-300ER means that as more A380 destinations come 'online', overall cargo tonnage may decrease in key ports-of-call.

Mr. Menen is unconcerned by this development, noting that the proliferation of A380 operations is often offset by the introduction of new frequencies and growing parallel opportunities. Mr. Berryman explains further, noting that should London Heathrow be overbooked for cargo, the company's scale enables it to transport freight to other UK destinations by road, such as Gatwick, Birmingham or Manchester - thus leveraging spare capacity to retain business and offsetting capacity losses (Boeing World Air Cargo Forecast, 2013).

Similarly, SkyCargo's movement of the entire pure freighter fleet (Aviation Week, 2014) to the new Dubai World Central (DWC) has seen it successfully grow operations between split hubs, with ample room to grow built into one of the world's largest cargo facilities (SkyCargo, 2014 / Boeing World Cargo Forecast 2013). This is underpinned by comparison with the mixed fortunes of Lufthansa Logistics, whereby SkyCargo's business model demonstrates that its core principal of independent financial operation, mixed with capabilities often being sourced at Group level provides a high degree of dynamism and fast reaction times.

Table 8 SkyCargo SWOT summary

\begin{tabular}{|l|l|}
\hline Strengths & Weaknesses \\
\hline Speed to market & Partial reliance on passenger airline \\
\hline Autonomy & \multirow{2}{*}{ A380 vs. B777 bellyhold disparity } \\
\cline { 1 - 2 } Broad Emirates network (Bellyhold) & Threats \\
\hline Opportunities & Weak and volatile global cargo market \\
\cline { 1 - 2 } Fast growing parent company & \\
\cline { 1 - 2 } Weakened competitors & \\
\cline { 1 - 2 } DWC hub growth &
\end{tabular}

\subsection{2 - DLM \& Travel Services: Business Trends Analysis}

Emirates' reputation as a 'travel agent friendly' airline (Arabian Industry, 2014) is underpinned by an integrated value chain servicing as many elements of the customer journey as possible. Fabio Prestijacopo, Vice President of DLM describes the company's 'Emirates Holidays' unit as a tour operator, but one whose primary mission is "to add value to the airline" by acting as an in-house direct sales channel. DLM units such as Emirates Holidays allow the Group to sell a complete package over which it has greater control.

Primarily, this avoids the need to monitor Service Level Agreements, as has been discussed with reference to MRO and Catering. Moreover, according to Laurie Berryman, it allows the Group to provide more competitive pricing, due to a reduction in servicing costs, such as GDS usage fees and agent commissions. Mr. Prestijacopo notes a correspondent benefit in gaining "greater ownership of the customer journey", allowing Emirates DLM to enhance service control and quality at a lower cost. 
From a financial perspective, DLM provides healthy, but relatively small revenues to the Emirates group, indicating that its true value is observed in its ability to support customer journeys, as observed above. Measurement of trends is somewhat limited by a fragmented business structure that until recently has been subject to a degree of duplication ${ }^{12}$ with multiple business units possessing similar capabilities. However, this can also have a highly positive impact on revenue, as seen in the acquisition of European Online Travel Agent (OTA) 'Travel Republic' (Travel Weekly, 2012) and the Gold Medal Travel Group (Dnata, 2014), a former unit of the Thomas Cook Group, which currently operates Netflights.com, a leading OTA in the UK market (Travel Weekly, 2012).

The 2014 Group Financial Report (Emirates Group Annual Report, 2014) observes that the acquisition of Travel Republic was instrumental in driving a revenue increase from USD153m in 2011 to UD210m in 2012. Mr. Berryman asserts that a further significant increase in the business will be seen in 2015, following the integration of the Gold Medal. The Group Financial Statement supports this, noting that "the full year impact... will be reflected only in the next financial year" (Emirates Group Annual Report, 2014). DLM and Travel Services revenue has more than doubled from USD109m in 2010, to USD231m in 2014 (Figure 14 below), with a relatively small corresponding increase in staff numbers indicating the sector's ability to grow fast without incurring steep increases in cost.

Figure 14 DLM \& Travel Services (combined) Revenue

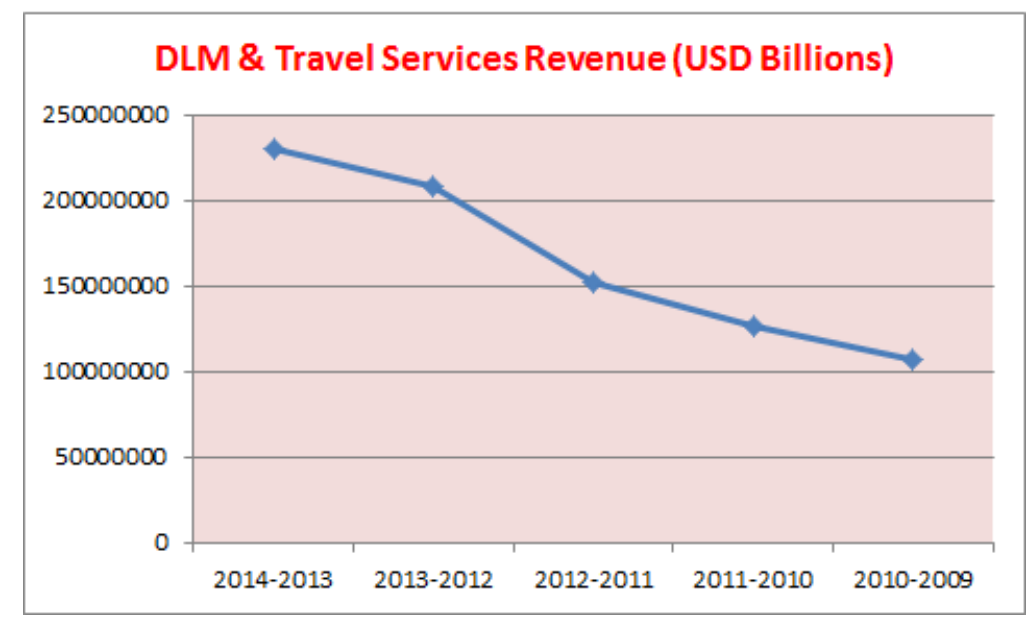

Source Adapted from Emirates Group Annual Reports 2009-2014

The Emirates Group sees potential to segment the direction of its DLM units, with Gold Medal continuing its role as an exclusive facilitator of Thomas Cook's car rental and air services needs, whilst integrating its objectives with the Emirates Group's overall aim of "continued tourism growth in the UAE" (Dnata, 2014). The end benefit to the Emirates Group can be inferred in Mr. Berryman's expectation that Gold Medal has the potential to drive larger numbers of Thomas Cook passengers to Emirates flights, as well as underpinning

\footnotetext{
${ }^{12}$ Fabio Prestijacopo points out that the functions of its Emirates Holidays and Dnata Travel brands have often overlapped in the past.
} 
Mr. Prestijacopo's comments about enhancing Emirates' capacity to provide in-house, integrated end-to-end journeys for its customers.

Travel Republic will remain within the pure OTA arena, with Emirates Holidays serving direct customers seeking an integrated package. This move towards specialised segmentation allows Emirates to maintain a significant presence in the travel services market, whilst reorientating this customer stream towards direct sales - reducing dependency on the travel agency partners that have long played a vital role in Emirates' commercial fortunes at a high cost-of-sale ${ }^{13}$.

Table 9 DLM \& Travel Services SWOT summary

\begin{tabular}{|l|l|}
\hline Strengths & Weaknesses \\
\hline Integral to Emirates Airline strategy & Fragmented business structure \\
\hline Customer 'ownership' & Relatively small player in a big global market \\
\cline { 1 - 2 } $\begin{array}{l}\text { No need to monitor Service Level } \\
\text { Opreements }\end{array}$ & Threats \\
\cline { 1 - 1 } Fast growing global market & Travel market can be volatile \\
\cline { 1 - 2 } Gold Medal acquisition & \multirow{2}{*}{ Strong incumbents (particularly OTAs) } \\
\hline
\end{tabular}

\subsection{3 - Catering: Business Trends Analysis}

The Emirates Group has seen its activity in the catering sector increase dramatically between 2014 and $2011^{14}$, despite experiencing the same depressed market as LSG SkyChefs. Following Dnata's acquisition and integration of the Alpha Catering Group (Emirates Group Annual Report, 2013) it was catapulted to the position of the fourth largest global catering provider. Prior to this, revenues were largely earned from the supply of third party clients at DXB. The financial context of this situation can be seen by growth between 2009 and 2014 totalling $900 \%$, or an increase from USD29m in 2010, to USD317m in 2014. The 2011 acquisition of Alpha reflects this in a 438\% increase in business between 2010 and 2011, with revenue moving from USD29m in 2010 to USD157m in 2011. The full integration of Alpha may be seen as having 'bedded down' in 2012, with a further increase to USD331m, realising the full potential of Alpha's revenues on the Group's balance sheet. Additionally, a dip for 2014 - 2013 may be explained by revenue sharing activities with the Lufthansa Group (see below).

\footnotetext{
${ }^{13}$ Personal interview with Laurie Berryman.

${ }^{14}$ Catering was not reported as an individual revenue stream by the Emirates Group until the 2010-11 financial year, reflecting the acquisition of the Alpha Catering Group.
} 
Figure 15 Emirates \& Dnata Catering (combined) Revenue

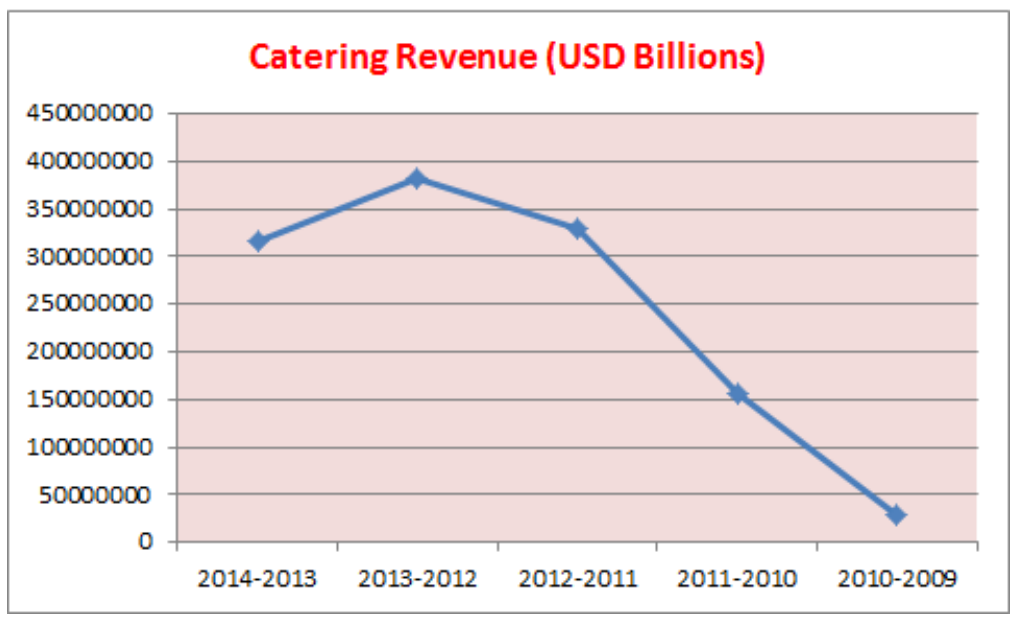

Source Adapted from Emirates Group Annual Reports 2009-2014

The Group's move away from a localised catering operation with limited third party capacity, to a globally orientated business resonates with the overall trends seen across other business areas of pursuing robust in-house capabilities, leveraged to their full potential by internationally focused third party revenue generation. Despite this, Emirates adopts a similarly pragmatic line to Lufthansa in its awarding of service contracts. Mr. Berryman points out that despite Alpha's global capabilities, the bidding process is still competitive for example, Emirates Airlines' catering needs at London Heathrow have been fulfilled by Do\&Co, an Austrian firm with worldwide operations, instead of Alpha ${ }^{15}$.

In the pursuit of cost-effective solutions, joint-ventures have emerged. 2012 saw the integration of Alpha's UK operations with those of LSG Skychefs, to form Alpha LSG (LSG Skychefs, 2014) - a UK only business, delivering USD512m in revenues with over 3,000 staff. Both Dnata and the Lufthansa Group retain a 50\% stake in the business and will share revenues which was formed with the intention of combating a particularly "challenging" marketplace in the UK and being able to meet new entrants more effectively (DFNI, 2012). This suggests that the growing presence of Do\&Co in the UK has become a sufficient enough cause for concern to the major incumbents to provoke a strategic response.

Further expansion may come in the form of LSG SkyChefs itself - a potential acquisition target for the Emirates Group's catering portfolio. Dnata has noted its interest in taking a stake (up to 49\%), or total ownership of SkyChefs, should the Lufthansa Group ultimately opt to divest this business unit. Given the two organisations prior experience of joint venture cooperation, it may be inferred that such an acquisition would be a good cultural and commercial fit for the Emirates Group. Furthermore, with the catering market poised to grow to USD16 billion by 2016 (PRWeb, 2013), such an acquisition would position Emirates as the global leader in a period of significant market recovery and growth.

\footnotetext{
${ }^{15}$ Personal interview with Laurie Berryman.
} 
This underpins The Emirates Group's strategy of leveraging business units for internal and external gain, with the majority of revenues ultimately being earned from third part work. The Alpha LSG joint venture, or any part-purchase of LSG SkyChefs also illustrates the pragmatic nature of its approach in a similar vein to its acquisition of Gold Medal Travel showing that it is willing to work with or for competitors such as SkyChefs or Thomas Cook and fuel their revenue generation, provided the strategic return to Emirates is sufficient to justify the investment.

Table 10 Catering SWOT summary

\begin{tabular}{|l|l|}
\hline Strengths & Weaknesses \\
\hline Positioned for global growth & Servicing parent company not guranteed \\
\hline Alpha flight catering's broad portfolio & Weak market (at present) \\
\cline { 1 - 1 } & Manpower intensive business \\
\hline Opportunities & Threats \\
\cline { 1 - 1 } Potential to acquire LSG SkyChefs & \multirow{2}{*}{ Growth of new suppliers (e.g. Do\&Co) } \\
\cline { 1 - 1 } Strong market growth predicted & \\
\hline
\end{tabular}

\section{Strategic analysis and positioning}

\subsection{Market growth and relative market share}

The BCG Matrix has been constructed on the basis of each BU's 'relative share' within its own market versus the growth rate for that market ${ }^{16}$.The highest growth rate was seen in the 'Travel Services' sector at $12 \%$ and the lowest in Flight Catering at 2\%, with relative shares falling between 100\% (for market-leaders such as SkyChefs) and less than 1\% (Emirates DLM).

Figure 16 BCG Matrix for EK and LH Business Unit

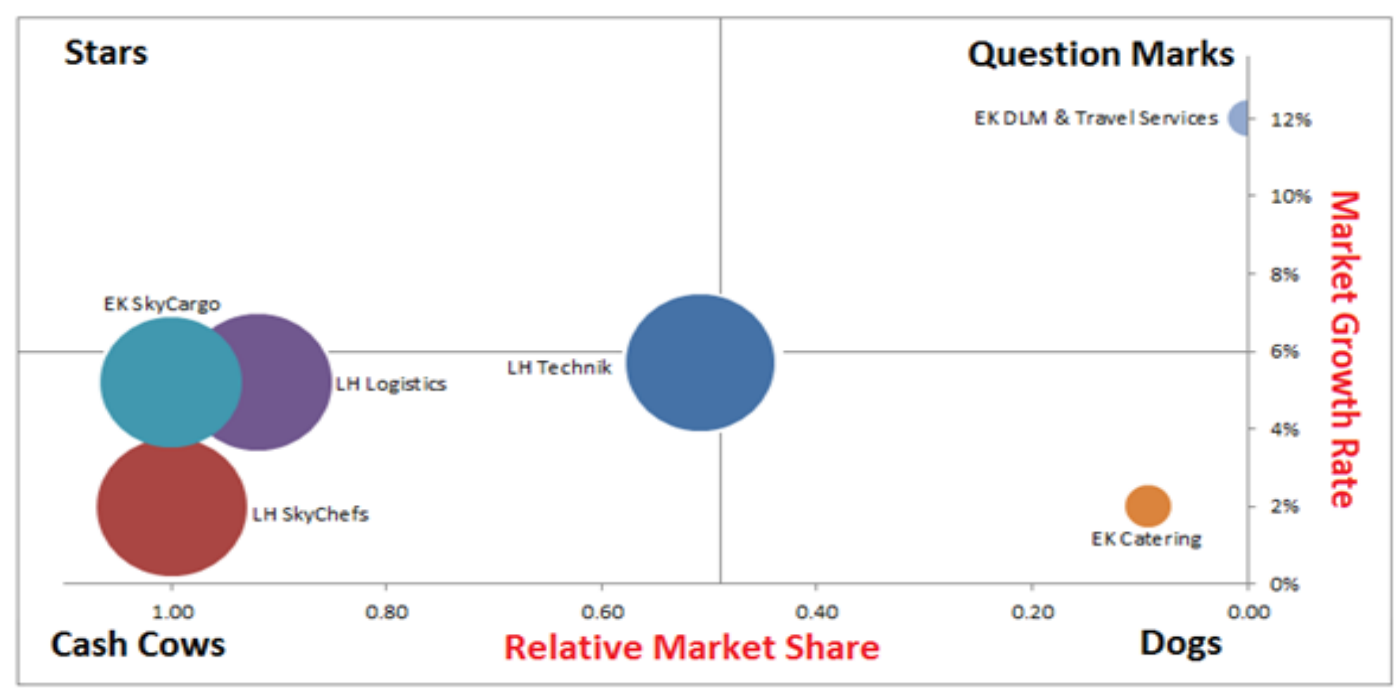

Source Author, from company \& industry reports

\footnotetext{
${ }^{16}$ Market growth rate is posited as an average of year-on-year growth figures between 2009 and 2014, sourced from company industry reports.
} 
The positioning of Emirates' BU's may initially appear surprising, with the majority achieving 'Dog' or 'Question Mark' status. However, the issue of potential is not fully covered by the BCG. For example, market growth rate is predicated on past, rather than predicted performance. The individual growth rates for business units is also not accounted for. The below Strategic Scoring Method establishes encouraging prospects for all of Emirates' business units. Conversely, although Lufthansa Technik may presently be a 'Cash Cow', it is unlikely to retain this positioning, with a slide towards 'Dog' or 'Question Mark' territory already evident from the BCG.

The following section analyses the market positioning established by the BCG, with added context from the Trend Analysis and SWOT summaries (section 4) to establish strategic value and direction for each $\mathrm{BU}$, the options available, as well as their associated risk.

\subsection{Strategic Value \& Directionality: Lufthansa}

Logistics is a 'Cash Cow'. The downturn in the freight market has resulted in low market and business unit growth, but its high relative market share in such a market demonstrates an ability to perform against wider trends. Additionally, a fairly positive future market outlook and a reduction in competitors due to the downturn present a healthy number of strategic options, including the ability to grow outside of Emirates SkyCargo's traffic flows. Logistics performs below the group average of a $4.3 \%$ margin, but a reinvigorated freight market could reverse this. Exposure to risk in the form of pure-freighter operations may be seen as a drain or a bonus but trading could improve if Lufthansa turned to pure bellyhold operations, due to the sharing of costs with the passenger division. Lufthansa may wish to retain Logistics and conduct a strategic review of operations. However, at present the cargo market remains a solid investment, so investment and building value may be viable options.

Technik is a 'Cash Cow' with the potential to slip into the 'Dog' or 'Question Mark' quadrants. Relatively flat BU and market growth and the prospect of OEM's eroding a currently strong relative share present a weak outlook. Technik's own admission that it is unwilling to pursue joint-ventures with OEM's and a risky play for intellectual property rights compounds this. Financially, Technik is a strong performer with outstanding margins backed by Lufthansa Group's steadily increasing profitability, although it must be noted that sluggish Group revenue growth may hamper cashflow and present Technik as a target for divestment in the face of future downturns. Technik may wish to review its strategic direction. If successful, it could stand to continue earning from presently strong margins and mitigate the influence of OEM's, but if it does not succeed, then sale may be an option in the long term.

SkyChefs is a 'Cash Cow', with the potential to move into 'Star' territory - this is due to its position as a market leader and forecasts of highly positive growth in the catering market. This establishes high potential value, which may not be fully accounted for in the rankings. The strategic benefits of controlling in-house catering operations are apparent, but the potential for sale underpins its financial value as well. However, a buyer could be Emirates, which could deliver value to an already strong competitor, diminishing the strategic 
attractiveness of selling the unit. Based on current market and business unit growth, it may appear to be an underachiever, but its strong future prospects may support retention as a prudent strategic and financial option in the short term. SkyChefs sits across boundaries, with an indicative direction pointing towards review and investment pending a decision regarding divestment. The intangibility of future prospects precludes a higher ranking, but Lufthansa may wish to retain and leverage the up-turn of the catering market.

Table 11 Lufthansa Business Unit Strategic Scoring Summary

\begin{tabular}{|c|c|c|c|c|}
\hline $\begin{array}{l}\text { Lufthansa } \\
\text { Logistics }\end{array}$ & Underachiever & $\begin{array}{l}\text { Weak } \\
\text { Performer }\end{array}$ & Strong performer & Best in Class \\
\hline Average Score & & \multicolumn{2}{|c|}{2.5} & \\
\hline $\begin{array}{l}\text { Indicative } \\
\text { Result }\end{array}$ & $\begin{array}{l}\text { 1. Consider Sale } \\
\text { or Restructure }\end{array}$ & $\begin{array}{l}\text { 2. Retain and } \\
\text { Review }\end{array}$ & $\begin{array}{l}\text { 3. Invest in BU } \\
\text { and Build } \\
\text { Value }\end{array}$ & $\begin{array}{l}\text { 4. Divest or } \\
\text { leverage }\end{array}$ \\
\hline $\begin{array}{l}\text { Lufthansa } \\
\text { Technik }\end{array}$ & Underachiever & $\begin{array}{l}\text { Weak } \\
\text { Performer }\end{array}$ & Strong performer & Best in Class \\
\hline Average Score & & \multicolumn{2}{|c|}{2.3} & \\
\hline $\begin{array}{l}\text { Indicative } \\
\text { Result }\end{array}$ & $\begin{array}{l}\text { 1. Consider Sale } \\
\text { or Restructure }\end{array}$ & $\begin{array}{l}\text { 2. Retain and } \\
\text { Review }\end{array}$ & $\begin{array}{l}\text { 5. Invest in } \\
\text { BU and } \\
\text { Build } \\
\text { Value }\end{array}$ & $\begin{array}{l}\text { 6. Divest or } \\
\text { leverage }\end{array}$ \\
\hline LSG SkyChefs & Underachiever & $\begin{array}{l}\text { Weak } \\
\text { Performer }\end{array}$ & Strong performer & Best in Class \\
\hline Average Score & & \multicolumn{2}{|c|}{2.6} & \\
\hline $\begin{array}{l}\text { Indicative } \\
\text { Result }\end{array}$ & $\begin{array}{l}\text { 1. Consider Sale } \\
\text { or Restructure }\end{array}$ & $\begin{array}{l}\text { 2. Retain and } \\
\text { Review }\end{array}$ & $\begin{array}{l}\text { 3. Invest in BU } \\
\text { and Build Value }\end{array}$ & $\begin{array}{l}\text { 4.Divest or } \\
\text { leverage }\end{array}$ \\
\hline
\end{tabular}

\subsection{Strategic Value \& Directionality: Emirates Group}

Emirates SkyCargo is a 'Cash Cow'. Market growth is low, but SkyCargo is growing rapidly against trends (and is the market leader, with a positive market outlook predicted). This is facilitated by drawing marketshare away from competitors. A cost-efficient structure, high revenues, a large flexible network, a new hub and a low risk of product and service development (see Section 5.4.2) result in a high number of strategic options. Volatility in the global cargo market, partial reliance on Emirates Airline's operations and not always securing priority use of internal resources may present financial challenges, but the strength of its parent serves to mitigate much of this. Emirates may wish to invest further in SkyCargo and build value through an increased global presence, as well as more robust dedicated freighter operations - reducing reliance on bellyhold capacity.

DLM \& Travel Services is a 'Question Mark' - low share in a large, fast growing global market obscures its true value. This sector is of high strategic value to Emirates by virtue of its high degree of integration with the passenger airline business. The acquisition of Gold Medal and future growth may provide necessary traction to transit to 'Star' territory, aided by average business unit growth of $137 \%$ between 2009-2014. However, high costs, a somewhat fragmented and duplicated business structure and a volatile marketplace serve to moderate its 
financial performance. Potential for significant strategic and financial rewards is high should Emirates invest in this sector - pursuing product and market development as priorities, as well as reviewing the business structure of the segment.

Emirates' Catering unit is a 'Dog' which could rapidly progress to being a 'Star'. Forecasting of a significant rebound in the catering market and the acquisition of Alpha Flight Catering (the results of which have not yet been fully realised) may serve to rapidly add financial and strategic value via increasing marketshare in a growing market. Potential acquisition of LSG SkyChefs would consolidate a position as a highly profitable market leader, but this remains only a possibility at present and cannot be fully accounted for in the rankings. To prepare for growth, Emirates may invest in its Catering division and attempt to build value through pursuing the acquisition of SkyChefs. If this is not possible, then it must retain Alpha and grow it with the market.

Table 12 Emirates Business Unit Strategic Scoring Summary

\begin{tabular}{|c|c|c|c|c|}
\hline $\begin{array}{l}\text { Emirates } \\
\text { SkyCargo }\end{array}$ & Underachiever & Weak Performer & $\begin{array}{l}\text { Strong } \\
\text { performer }\end{array}$ & Best in Class \\
\hline Average Score & & \multicolumn{2}{|c|}{3} & \\
\hline $\begin{array}{l}\text { Indicative } \\
\text { Result }\end{array}$ & $\begin{array}{l}\text { 1. Consider Sale } \\
\text { or Restructure }\end{array}$ & $\begin{array}{l}\text { 2. Retain and } \\
\text { Review }\end{array}$ & $\begin{array}{l}\text { 3. Invest in BU } \\
\text { and Build Value }\end{array}$ & $\begin{array}{l}\text { 4.Divest or } \\
\text { leverage }\end{array}$ \\
\hline $\begin{array}{l}\text { Emirates DLM } \\
\text { and Travel } \\
\text { Services }\end{array}$ & Underachiever & Weak Performer & $\begin{array}{l}\text { Strong } \\
\text { performer }\end{array}$ & Best in Class \\
\hline Average Score & & \multicolumn{2}{|c|}{3} & \\
\hline $\begin{array}{l}\text { Indicative } \\
\text { Result }\end{array}$ & $\begin{array}{l}\text { 1. Consider Sale } \\
\text { or Restructure }\end{array}$ & $\begin{array}{l}\text { 2. Retain and } \\
\text { Review }\end{array}$ & $\begin{array}{l}\text { 3.Invest in BU } \\
\text { and Build Value }\end{array}$ & $\begin{array}{l}\text { 4.Divest or } \\
\text { leverage }\end{array}$ \\
\hline $\begin{array}{l}\text { Emirates } \\
\text { Catering }\end{array}$ & Underachiever & Weak Performer & $\begin{array}{l}\text { Strong } \\
\text { performer }\end{array}$ & Best in Class \\
\hline Average Score & & \multicolumn{2}{|c|}{2.75} & \\
\hline $\begin{array}{l}\text { Indicative } \\
\text { Result }\end{array}$ & $\begin{array}{l}\text { 1. Consider Sale } \\
\text { or Restructure }\end{array}$ & $\begin{array}{l}\text { 2. Retain and } \\
\text { Review }\end{array}$ & $\begin{array}{l}\text { 3. Invest in BU } \\
\text { and Build Value }\end{array}$ & $\begin{array}{l}\text { 4.Divest or } \\
\text { leverage }\end{array}$ \\
\hline
\end{tabular}

\subsection{Strategic Options \& Risk}

The Ansoff matrix can be useful for honing the strategic positioning as developed above into actionable, sustainable strategies and supplementing the directionality established by the Strategic Scoring Method through the identification of specific areas for development by assessing value-to-risk relationship between new and existing business areas.

\subsection{1 - Lufthansa}

Market development for Lufthansa Group presents an issue in light of the fact that progression of the business may be dependent on retraction or significant review in some areas (notably MRO), as opposed to further market penetration or product and market development. However, as no Lufthansa Group business unit fell into the 'Consider Sale' category, room for review and assessment of the risk of continuing in such sectors means that value can still be drawn from the Ansoff matrix. 
Table 13 Lufthansa Group Ansoff Matrix

\begin{tabular}{|c|c|c|}
\hline Lufthansa & EXISTING PRODUCTS / SERVICES & NEW PRODUCTS / SERVICES \\
\hline \multirow{3}{*}{ 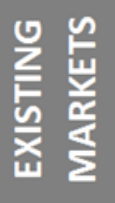 } & Market Penetration & Product / Service Developmen \\
\hline & Catering: Leverage upcoming market growth & \multirow{2}{*}{ MRO: Spares manufacturing } \\
\hline & Logistics: Pursue market recovery & \\
\hline \multirow{3}{*}{$\frac{3}{z} \frac{\vec{w}}{\frac{w}{c}}$} & Market Extension / Development & Diversification \\
\hline & MRO: Develop new locations (SE Asia) & \multirow{2}{*}{ MRO: Spares manufacturing } \\
\hline & $\begin{array}{l}\text { Logistics: Stimulate new markets outside of Gulf } \\
\text { airlines' influence (Eastern Europe) }\end{array}$ & \\
\hline
\end{tabular}

A lower risk alternative for Lufthansa Group could be developing new maintenance bases in areas of market growth, such as South East Asia, which has seen a proliferation of LCC's with a preference for outsourcing. Consequently, the region's market value is predicted to see growth to USD73 billion by 2023 (AFM, 2013). Additionally, new markets for Logistics that lie outside of the east-bound traffic flow directionality of gulf carriers, such as Eastern Europe, could prove lucrative with little risk. Spares manufacturing represents another high risk strategy. Although Technik does currently hold a limited stake in spares manufacturer HEICO Aerospace (Lufthansa Group Annual Report, 2014), section 4 showed that far greater investment in this sector is required to effectively combat the entrance of OEM's. The risks to making further investments in a declining sector are apparent, however, should Technik be successful in acquiring greater manufacturing capability, or the intellectual property rights necessary to become a significant spare parts manufacturer, then the benefits may well outweigh the risks.

Finally, the pursuit of recovering growth trends in existing markets could be taken advantage of by Catering and Logistics. The fact that both have survived market contraction and retained market leading positions may allow them to leverage this advantage into drawing marketshare away from weakened competitors.

\subsection{2 - Emirates}

The Emirates Group's strong positioning as shown earlier provides a positive outlook for the development of all of its BU's. However, expansion is nevertheless subject to risk, especially where the financial and strategic gains are likely to be largest, by virtue of the capital outlay required to diversify. 
Table 14 Emirates Group Ansoff Matrix

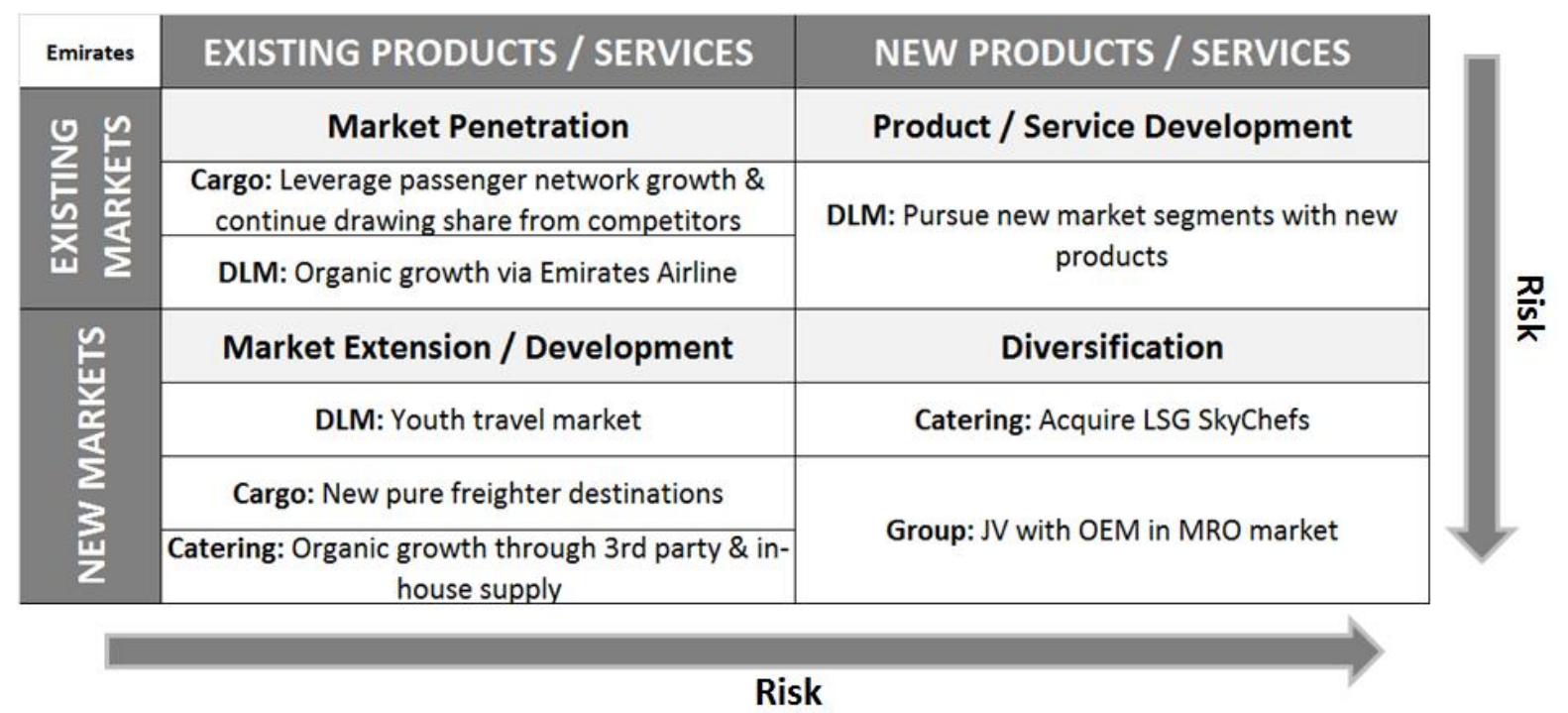

Expansion into the youth travel market may open new opportunities for DLM and Travel Services, whilst utilising its existing infrastructure - partially financially de-risking the move. The youth travel market is expected to grow to 73\% from present levels to USD 320 billion by 2020 and represent up to $20 \%$ of global tourism (SYTA, 2012), representing a highly fertile segment in which to expand. Cargo's continued growth could be facilitated by expanding to new pure freighter markets - reducing its reliance on Emirates Airline's network expansion for growth, by adding capacity in high potential regions such as South East Asia and expanding trucking operations (Boeing World Air Cargo Forecast 2013).

The acquisition of LSG SkyChefs - should Lufthansa opt for sale - represents a significant gain for Emirates, however the significant capital outlay required to meet its 2012 estimated valuation of USD 1.1 billion (Morgan Stanley, 2012) and the prospect of projected market growth failing to materialise increase the risk of pursuing this option. It is nevertheless offset by the potential to move into 'Star' territory, should acquisition prove possible and successful.

DLM and Travel Services may opt to continue growing organically through its integration with Emirates Airline. Laurie Berryman notes that one of the strongest areas for growth in Emirates' portfolio has been "three and four star" travel, as opposed to Dubai's typical association with five star luxury. This growth in lower value, fed by organic volume growth in line with the carriers ambitious expansion plans could significantly grow marketshare, contributing to its move into the 'Star' BCG quadrant.

Similarly to Lufthansa Logistics, its survival of the global cargo market downturn, the subsequent elimination of competitors and its market-leading presence position it well to continue growing within a relatively static market at the expense of its competitors. As a parallel opportunity to developing new pure freighter operations, it may also continue to rely on the organic growth of its bellyhold network. 


\section{Recommendations \& Conclusion}

This study has uncovered the following conclusions:

1. The strategic value of a diversified portfolio of related, non-core subsidiaries can be illustrated by the Emirates Group's investment in Travel Services as a cost-effective method of feeding its core passenger transport business through exercising greater end-to-end control over the consumer journey. In the case of LSG SkyChefs, the Lufthansa Group informs strategic value somewhat differently. Despite LSG primarily adding financial value to the group, it also acts as a strategic asset when the issue of divestment to a major competitor is considered. As such, the strategic value of a business unit may be defined in different ways, dependent upon diverging trends and approaches in each company.

2. Individual and comparative analysis of business unit strengths and weaknesses revealed that differing forces driving business units may be symptomatic of both industry pressures and parent company strategy. For example, Lufthansa Technik appears likely to fall foul of a changing landscape in the MRO industry, but is presently well supported and necessary to the Lufthansa Group's operations. Conversely, despite relative autonomy from its parent, Emirates SkyCargo performs strongly. As seen in section 4, it is the belief of its most senior management that this is a strength afforded in part due to the Emirates Group's strategy of non-interference and internal competition for resources.

3. An upturn in the global catering market, a downturn in in-house MRO operations at the hands of OEM's and steady growth in the travel services and cargo markets have all been independently explored. Furthermore, insight has been gained into the potential for growing relationships between diversified business units and corecompetencies (particularly in Travel Service), as well as a business-unit-to-businessunit view.

4. Carriers wishing to diversify, or review their current diversified portfolio may draw on the examples of Emirates and Lufthansa to understand and relate to the trends informing success or failure in the sectors covered.

Specific recommendations for Emirates and Lufthansa based on the main findings are as follows:

Lufthansa: Growing financial strength for the Group, mirrored by growth amongst its business units illustrates that Lufthansa's diversification strategy has proved a positive addition thus far. However, a weak market outlook for Technik and uncertainty over SkyChefs' future with the Group may cast some doubt on Lufthansa continuing as a widelydiversified business. SkyChefs in particular must be handled with care, due to potential to contribute significantly to the Group's strategic and financial positioning. Lufthansa's bias towards financial value over strategic value is indicative of its squeezed market position and catering to shareholders, but it must be careful not to divest or retract from sectors with weaker margins that are strategically crucial to supporting core-functions (such as Cargo). Divestment of business units may not be a wise option for Lufthansa at present unless its 
need to generate cash becomes more pressing. Nevertheless, this research points to a clear need for a review of strategic options available to each business unit and the pursuit of greater efficiencies in tandem with investment in product and service development. It is crucial that Lufthansa's business units keep abreast of market trends to ensure their continued viability, as in some areas - particularly Technik- it is in danger of falling behind.

Emirates: Although Emirates is not experiencing the same financial pressures as Lufthansa and exhibits a clear bias towards strategic positioning over financial growth, it is nevertheless clearly a pragmatically run business - the sale of Mercator being particularly indicative of this. The outlook for all of its business units is positive, with no immediate requirement for divestment, but restructuring to eliminate duplication and leverage the strength of the Emirates brand would benefit both Catering and DLM and Travel Services.

DLM and Travel Services and SkyCargo strategic contribution to the group is high and much like Lufthansa, should be subject to further investment to continue driving growth both within the passenger airline, but also other business units. Provided catering market forecasts are accurate, Catering has a bright future through organic growth (Alpha) or acquisitions (SkyChefs), but the value of this unit is not primarily strategic, as demonstrated by Emirates' willingness to award third party contracts. As such, should growth targets fall short, further outsourcing may be considered as a long-term option.

Overall the study has demonstrated that, although both airline groups operate their business units as Profit and Loss (P\&L) centres, Lufthansa exercises a decentralised structure, positioning its business units as standalone companies focussed on financial health. Conversely, Emirates Group's business units draw upon a centralised resource pool, with managerial autonomy and an emphasis on strategic positioning. The strengths and weaknesses of each approach are comparatively scored and analysed, with the results of each being largely dependent on both the operating environment of each group and the basis of their strategic approach.

The strengths and weaknesses of diversification may be clearly seen in Emirates and Lufthansa - two very different companies pursuing diversification from differing angles. Any weakness in the results borne by Lufthansa's diversification strategy may be seen as primarily linked to the Group's greater exposure to a market squeezed by low-cost competition and encroaching Gulf carriers. This forces the need to extract maximum financial value from its business units whilst countenancing cost-cutting and even market exit to strengthen its financial position. The result of this is a bias towards financial return in its diversification strategy, rather than one that is purely strategic.

It is possible that diversification can act as a drain on resources, particularly when the parent company loses sight of changing market trends and fails to adapt its business units, due to a diminished stress on strategic oversight. The progress of the Lufthansa SCORE programme is apparent in the strengthening of financial results, but this may yet cause Lufthansa to re-focus on core-competencies, rather than maintaining a diversified structure. 
The Emirates case has shown that the primary benefit of diversification has arguably been strategic, supporting Pakneiat et al's (2010) notion that a strategy dominated logic is more likely to pay dividends. This also shows that intangible factors such as enhancement of competencies and the ability to support internal development are crucial benefits in informing parent company profitability. Emirates' stronger financial standing, with margins almost double Lufthansa's, despite lower revenues, and the higher overall scoring of Emirates' business units in section 4 over Lufthansa may indicate a stronger basis for diversification. Additionally, the cost-collapse associated with the resource sharing combined with managerial independence allowed Emirates' units to act as a significant strength.

It is important to note that any airline wishing to take the insights uncovered in this paper as a source of advisory should first ensure that their grounds for comparison are relevant, as each group in isolation does ultimately present a positive overall case for diversifying. Indeed, the weaknesses in overall strategy are generally only apparent when viewed on a comparative basis. It is also crucial to note that the evidence strongly suggests that the success of a diversification strategy is less informed by the scope or resources of the parent organisation, than by the manner in which it administers its strategy.

The research is limited by a lack of disaggregate financial data, which prevented to the development of some comparable KPI's (e.g. ROCE). Further data likely to be unavailable for public analysis (e.g. factors informing goodwill or amortisation of assets) would require assessment, which may reveal further underlying value in retention or sale, but is not published by either group. Additionally, the Emirates Group does not publish business unit profitability statements, precluding a more in-depth analysis of its operations. As such, rankings and final assessment have produced indicative conclusions only. Interrogation into the drivers of low cost carrier diversification (e.g. the Easy Group) would provide further industry-level insights. Analysis of all business units operated by Emirates and Lufthansa may also provide a more detailed insight into their overall strategies.

\section{Acknowledgements}

The authors are very grateful to the following experts for their generous cooperation in this study, Mr. Giovanni Bisignani - CEO \& General Secretary, IATA (ret), Mr. Ram Menen Divisional Senior Vice President, Emirates SkyCargo (ret), Mr. Laurie Berryman - Vice President UK, Emirates Airline, Mr. Fabio Prestijacopo - Vice President Business Support DLM, Emirates Group, Herr Harald Heppner - Manager Corporate Strategy, Lufthansa Group, Herr Sadiq Gallani - Director Corporate Strategy, Lufthansa Group, Dr. Tazeeb Rajwani - Senior Lecturer in Strategy, Cranfield School of Management. 


\section{References}

Aaker, D. (2004), Leveraging the Corporate Brand, California Management Review, Volume 46, Spring - Adapted from Brand and Portfolio Strategy by Aaker, D.

AFM (2013). Eastern promise: Examining South-East Asia's MRO. Available online at: http://www.afm.aero/magazine/maintenance-operations/item/752-eastern-promiseexamining-south-east-asia-s-mro (accessed 20/07/14)

Al-Kaabi, H Potter, A Naim, M (2007) An outsourcing decision model for airlines' MRO activities, Journal of Quality in Maintenance Engineering, Vol. 13 Iss: 3, pp.217 - 227.

Airline Cargo Management (2013). Moving the freight of the world. Available online at: http://www.airlinecargomanagement.com/feature/alcm-speaks-to-atlas-air-bill-flynn-andmichael-steen?session_id=mt2o6k92nl8se2oq333llchi97 (accessed 15/06/14).

AMA (2010). What makes brands elastic? Available online at: https://archive.ama.org/archive/AboutAMA/Pages/AMA\%20Publications/AMA\%20Journ als/Journal\%20of\%20Marketing/TOCs/SUM_2010.3/What_Makes_Brands_Elastic.aspx (accessed 15/05/14).

Ansoff, I (1957). Strategies for diversification, Harvard business review. Vol 35, Issue 5, pg 113-124.

Arabian Industry (2014) Top Trade Friendly Airlines in the Middle East. Available online at: http://arabianindustry.com/travel/photos/2014/jul/7/top-trade-friendly-airlines-in-themiddle-east-4754646/\#.U8fVefldV8E (accessed 06/06/14)

Aviation Week (2014) Dubai World Central Move in 2020 Not Impossible, says Emirates President. Available online at: http://aviationweek.com/commercial-aviation/dubai-worldcentral-move-2020-not-impossible-says-emirates-president (accessed 15/06/14)

Aviation Week (2014) New Volume Rules Change MRO Capability Investments. Available online at: http://aviationweek.com/mro/new-volume-rules-change-mro-capabilityinvestments (accessed 03/07/14)

Aviation Week (2013) OEM and MRO Battleground? Available online at: http://aviationweek.com/blog/oem-and-mro-battleground-mroee (accessed 26/06/14)

Aviation Week (2012). Evolution of the European MRO Market. Available online at: http://events.aviationweek.com/html/meu12/Gen\%20Ses\%20Oct\%2011\%20JONAS_BUT AUTIS.pdf (accessed 13/06/14).

Berger, A., Humphrey, D. (1991), The dominance of inefficiencies over scale and product mix economies in banking. Journal of Monetary Economics, Volume 28, Issue 1, August 1991, Pg. 117-148.

Bloomberg (2013) Emirates Interested in Buying Top Airline Caterer from Lufthansa. Available online at: http://www.bloomberg.com/news/2014-05-13/emirates-interested-inbuying-top-airline-caterer-from-lufthansa.html (accessed 15/07/14)

Boeing World Air Cargo Forecast (2013). Commercial Market Outlook: Air Cargo. Available online at: http://www.boeing.com/boeing/commercial/cmo/air_cargo_market.page (23/06/14).

Campbell, A (1992). Brief case: why do companies over-diversify? Long Range Planning, Vol 25, Issue 5, pg 114-116.

CAPA (2014) Asian air cargo overview: different profiles for major freight airlines but united in weak outlook. Available online at: http://centreforaviation.com/analysis/asianair-cargo-overview-different-profiles-for-major-freight-airlines-but-united-in-weakoutlook-173842 (accessed 05/07/14)

CAPA (2014). Unit cost analysis of Emirates, IAG \& Virgin; about learning from a new model, not unpicking it. Available online at: http://centreforaviation.com/analysis/unitcost-analysis-of-emirates-iag--virgin-about-learning-from-a-new-model-not-unpicking-it- 
147262 (accessed 05/05/14) CAPA (2013). Air France-KLM: 'on the way to being saved' or are new measures not radical enough? Available online at:

$\mathrm{http}$ ://centreforaviation.com/analysis/air-france-klm-on-the-way-to-being-saved-or-arenew-measures-not-radical-enough-132171 (accessed 02/06/14).

CAPA (2013). Delta Airlines pledges profitability for its Trainer oil refinery business in 2014. Available online at: http://centreforaviation.com/analysis/delta-air-lines-pledgesprofitability-for-its-trainer-oil-refinery-business-in-2014-145985 (04/06/14).

CAPA (2011). Delta to acquire stake in Aeromexico as part of expanded alliance. Available online at: http://centreforaviation.com/analysis/delta-invests-usd65m-in-aeromexico-in-usmexico-partnership-56961 (accessed 28/06/14)

Chavas, J. Kim, K. (2010). Economies of diversification: A generalization and decomposition of economies of scope. International Journal of Production Economics 126.2 (2010): 229235.

CNBC (2013). Delta's jet fuel gamble is starting to pay off. Available online at: http://www.cnbc.com/id/101253932\# (accessed 04/06/14).

Day, G. S. (1990). Market driven strategy: Processes for creating value. New York: Free Press.

DFNI Online (2012) Alpha LSG Merger Gets Green Light. Available online at : http://www.dfnionline.com/article/Alpha-LSG-merger-gets-green-light-1862318.html (accessed 05/07/14).

Dinopoulos, E. (1994) Schumpeterian growth theory: An overview. Osaka City University Economic Review 29.1 (1994): 1-21.

Dnata (2014) Dnata acquires UK-based travel company, Gold Medal Group. Available online at:

http://www.dnata.com/english/media/news/news.aspx article=1546047\&al=0\&offset=0\&f $\mathrm{d}=20040101010101 \& \mathrm{td}=20140405235959$ (accessed 05/06/14).

DW/Reuters (2012). Luftansa to Sell LSG SkyChefs in cost-cutting plan. Available online at: http://www.dw.de/lufthansa-to-sell-lsg-sky-chefs-in-cost-cutting-plan/a-15996472 (accessed 12/05/14).

Emirates Group Annual Reports (2014) Available online at: http://www.theemiratesgroup.com/english/facts-figures/annual-report.aspx, for financial years 2009-2014.

Flight Global (2013). Singapore Special Report: MRO. Available online at: http://www.flightglobal.com/features/singapore-special/mro/ (accessed 22/06/14)

Flight Global (2011). Maintenance special report: The MRO quandary. Available online at: http://www.flightglobal.com/news/articles/maintenance-special-report-the-mro-quandary348942/ (accessed 15/06/14)

Geringer, J., Tallman, S., and Olsen, D. (2000). Product and international diversification among Japanese multinational firms, Strategic Management Journal, 21, 51-80.

Grosskopf, S., Hayes, K., Yaisawarng, S. (1992), Measuring Economies of Diversification: A Frontier Approach, Journal of Business \& Economic Statistics, Volume 10, Issue 4, Pg. $453-459$.

Heikkilä, J., Cordon C (2002). Outsourcing: a core or non-core strategic management decision? Strategic Change 11.4, pp183-193.

Heracleous, L., Wirtz, J., Jonston, R. (2004), Cost-effective service excellence: lessons from Singapore Airlines, Business Strategy Review. Volume 15, Issue 1, pages 33-38

Heracleous, L., Wirtz, J (2009) Strategy and organization at Singapore Airlines: Achieving sustainable advantage through dual strategy, Journal of Air Transport Management, 15, pp274-279 
Hitt, M.A., Hoskinsson, R.E., and Kim, H. (1997). International diversification and firm performance in product-diversified firms, Academy of Management Journal, 40 (4), pp. 767-798.

Holloway, S. (2008). Straight And Level: Practical Airline Economics, Ashgate Ltd, Aldershot, UK. ISBN 978-0-7546-7258-6.

IATA (2014) Moderate Growth for Air Cargo in 2013 - Full Performance Statistics Released. Available online at: http://www.iata.org/pressroom/pr/Pages/2014-02-0501.aspx (accessed 05/07/14).

IATA (2013). Profits Grow in 2013, But at a Slower Pace - Upward Trend to Continue in 2014. Available online at: http://www.iata.org/pressroom/pr/Pages/2013-09-23-01.aspx (accessed 15/06/14)

Irish Independent (2013) Union Slams Lufthansa Technik Plant Closure. Available online at: http://www.independent.ie/irish-news/union-slams-lufthansa-technik-plant-closure29758019.html (accessed 26/06/14)

Jenkins, M., Rajwani, T., Verity, J. (2012) The Tune Group. Cranfield University.

Jones, P (2007), Flight Catering, Behr's Verlag, Hamburg, Chpt, 1,4,1, 39-55, available online at: http://epubs.surrey.ac.uk/2200/2/E66589A3.pdf (accessed: 19/05/2014)

Ketler, K. Walstrom, J. (1993) The outsourcing decision, International journal of information management. Vol 13, Issue 6, 449-459.

Kilpi, J, and Ari, V. (2004) Pooling of spare components between airlines. Journal of Air Transport Management 10.2: 137-146.

Kock, K.J. and Guillen, M.F. (2001), Strategy and structure in developing countries, business groups as an evolutionary response to opportunities for unrelated diversification, Industrial and Corporate Change, Vol. 10 No. 1, 77-113.

Krishnan, V., and Ellis, B (2008). Berkshire Hathaway: A Successful Conglomerate and Not Just a Mutual Fund! Available online at: http://abeweb.org/proceedings/proceedings10/krishnan.pdf (accessed 18/05/14).

LH SCORE Expert Session (2013), Available online at: http://investorrelations.lufthansagroup.com/en/veranstaltungen/conferences-roadshows/score-expertsession-062013.html

Lindstädt, H., Fauser, B. (2004), Separation or integration? Can network carriers created distinct business streams on one integrated production platform? Journal of Air Transport Management, vol 10, issue 1, January 2004, 23 - 31.

LSG SkyChefs (2014), Available online at: http://www.lsgskychefs.com/media/

Lubatkin, M., Rogers, R. (1989), Diversification, Systematic Risk, and Shareholder Return: A Capital Market Extension of Rumelt's 1974 Study. Academy of Management Journal, Vol. 32, No.2. 454-465.

Lufthansa Group Annual Report (2014) Available online at: http://investorrelations.lufthansagroup.com/en/finanzberichte.html

Lufthansa Group Annual Report (2013) Available online at: http://investorrelations.lufthansagroup.com/en/finanzberichte.html

Monga, A. John, D. (2010) What Makes Brands Elastic? The Influence of Brand Concept and Styles of Thinking on Brand Extension Evaluation. Journal of Marketing, Vol. 74, Pg. 8092.

Morgan Stanley (2012). LSG SkyChefs Divestment Outlook. Available online at: http://linkback.morganstanley.com/web/sendlink/webapp/BMServlet?file=cd33osge-3oceg000-abd3001a64f36100\&store $=0 \& \mathrm{~d}=\mathrm{UwBSZXN1YXJjaAA0MjIwNzA} \% 3 D \& u s e r=k f h 9 w 5 \times 5 \mathrm{a} 81 \mathrm{~b}-$ 8\&_gda_=1461453314_f80c71263701ff06477b1b808d701659 (accessed 15/06/14) 
Morrell, P. (2007), Air Cargo Economics. Available online at: http://recil.grupolusofona.pt/bitstream/handle/10437/2629/artg8.pdf?sequence=1 (accessed 20/07/14).

O'Connell, JF. (2007) The strategic response of full service airlines to the low cost carrier threat and the perception of passengers to each type of carrier, Cranfield University.

Pakneiat, M., Panahi, M., Noori, J. (2010) Firm Capabilities and diversification: how mission matters. Business Strategy Series, vol. 11, issue 4, pg 248 -260. Park, C, Milberg S, Lawson, R.(2001) Evaluation of brand extensions: the role of product feature similarity and brand concept consistency., Journal of Consumer Research, 185-193.

Park, C.W., Jaworski, B.J., MacInnis, D.J. (1986), Strategic brand concept image management, Journal of Marketing, Volume 50, 135-45.

Porter K, (1980), How Competitive Forces Shape Strategy, Harvard Business Review, Pg 137 - 145. Available online at: http://faculty.bcitbusiness.ca/KevinW/4800/porter79.pdf (accessed 13/05/14)

Pringle, H., Field, P, (2008). Brand Immortality: How Brands Can Live Long and Prosper, MPG Books Ltd, Bodmin, Cornwall. ISBN 978-0-7494-4928-5

PRWeb (2013). Rising Passenger Traffic Augurs Well for In-Flight Catering Services Market, According to New Report by Global Industry Analysts, Inc. Available online at: http://www.prweb.com/releases/in_flight_catering/airline_food_services/prweb10502738. htm (accessed 12/07/14)

Rodgers, E. (1996). Flying High : The Story of Boeing and the Rise of the Jetliner Industry. Eugene Rodgers. Atlantic Monthly Press, New York.

SkyCargo (2014) Emirates SkyCargo Completes Another Remarkable Year. Available online at: http://www.skycargo.com/english/media-centre/media-news-pressdetails.aspx?id=1501182 (accessed 20/06/14)

SkyCargo (2014) Emirates SkyCargo Terminal (DWC). Available online at: http://www.skycargo.com/english/about-us/DWC/DWC.aspx (accessed 21/06/14).

SkyCargo.com (2009), Available online at: http://www.skycargo.com/english/mediacentre/media-news-press-details. aspx?id=424755

Suen, W. (2002) Alliance strategy and the fall of Swissair, Journal of Air Transport Management, 8.5, 355-363.

SYTA (2012). Student \& Youth Travel. Available online at: http://www.syta.org/downloads/Student\%20and\%20Youth\%20Travel\%20Digest\%20Pres entation.pdf (accessed 22/06/14)

Taneja, N. (2004), Simpli-flying - Optimizing the Airline Business Model, Ashgate, United Kingdom. ISBN: 0754641937.

Teece, D. Pisano, G. Shuen, A (1997). Dynamic capabilities and strategic management, Strategic Management Journal, 18(7), 509-533.

Teece, D. (1986) Transactions cost economics and the multinational enterprise An Assessment, Journal of Economic Behavior \& Organization 7.1, 21-45.

TNT Airways (2012). TNT Airways and Emirates SkyCargo sign code-share agreement. Available online at: http://www.tnt.com/corporate/en/data/press/2012/03/tnt-airways-andemirates-skycargo-sign-code-share-agreement.html (accessed 20/05/14).

Travel Weekly (2012) Travel Republic Sold. Available online at: http://www.travelweekly.co.uk/articles/2012/01/03/39180/travel-republic-sold.html (accessed 05/06/14). 